\title{
Steller sea lion foraging response to seasonal changes in prey availability
}

\author{
Michael F. Sigler ${ }^{1, *}$, Dominic J. Tollit ${ }^{2, *}$, Johanna J. Vollenweider ${ }^{1}$, \\ John F. Thedinga ${ }^{1}$, David J. Csepp ${ }^{1}$, Jamie N. Womble ${ }^{1}$, Mandy A. Wong ${ }^{2}$, \\ Michael J. Rehberg ${ }^{3}$, Andrew W. Trites ${ }^{2}$ \\ ${ }^{1}$ National Oceanic and Atmospheric Administration, National Marine Fisheries Service, Alaska Fisheries Science Center, \\ 17109 Point Lena Loop Road, Juneau, Alaska 99801-8626, USA \\ ${ }^{2}$ Marine Mammal Research Unit, Fisheries Centre, University of British Columbia, 2202 Main Mall, Vancouver, \\ British Columbia V6T 1Z4, Canada \\ ${ }^{3}$ Alaska Department of Fish and Game, Statewide Marine Mammal Program, 525 West 67th Avenue, Anchorage, \\ Alaska 99518-1599, USA
}

\begin{abstract}
We hypothesized that: (1) Steller sea lion Eumetopias jubatus diet choice is a function of prey availability, (2) sea lions move to take advantage of times and locations of seasonal prey concentrations and (3) the number present depends on the amount of prey available (numerical response). Over 3 yr, typically on a quarterly basis, in Frederick Sound, SE Alaska, multiple measurements were taken of Steller sea lion abundance (aerial surveys), diet (scats), dive behavior (satellite telemetry) and prey availability and caloric density (nearshore, pelagic and demersal fish surveys). We found that Steller sea lions shifted diet composition in response to changes in prey availability of pollock Theragra chalcogramma, hake Merluccius productus, herring Clupea pallasi and salmon Oncorhynchus spp. They selected intermediate-sized fish and avoided small $(<10 \mathrm{~cm})$ and large $(>60 \mathrm{~cm})$ fish, and moved between areas as prey became available seasonally. The number of sea lions present depended on the amount of prey available; a standing biomass of 500 to $1700 \mathrm{t}$ of prey in a nonbreeding area such as Frederick Sound, depending on species composition, can attract and sustain about 500 sea lions. Pollock was more frequent in sea lion diet in inside waters of SE Alaska —including Frederick Sound, Stephens Passage and Lynn Canal - than anywhere else in Alaska and contributed $\sim 1 / 3$ of the dietary energy in Frederick Sound. This finding implies that a diet with substantial year-round contributions from less nutritious, but abundant prey such as pollock can form part of a healthy diet as long as more nutritious prey such as herring, salmon or eulachon Thaleichthys pacificus also are consumed. Our study supports the conclusion that the Steller sea lion is an opportunistic marine predator with a flexible foraging strategy that selects abundant, accessible prey and shifts among seasonally available species.
\end{abstract}

KEY WORDS: Prey availability $\cdot$ Foraging $\cdot$ Steller sea lion $\cdot$ Prey selection $\cdot$ Diet $\cdot$ Walleye Pollock · Herring

\section{INTRODUCTION}

Animals should forage in a way that optimizes their energy intake and, ultimately, fitness. Multiple factors influence foraging behavior, including predation risk and prey availability. Air-breathing mammals and birds foraging underwater are additionally challenged by the need to resupply oxygen stores frequently. Some marine mammals specialize (Ostfeld 1982, Ford \& Ellis 2006), while others feed opportunistically on the most abundant prey within a suite of preferred species (Thompson et al. 1991, Bowen \& Harrison 1994, Tollit et al. 1997a) and switch prey when prey abundance changes (Bailey \& Ainley 1982, Sinclair et al. 1994, Tol- 
lit et al. 1997a, Weise \& Harvey 2008). Mammalian and avian predators often move to take advantage of daily (Coyle et al. 1992, Hunt et al. 1998) or seasonally abundant prey including Atlantic Clupea harengus (Similä et al. 1996, Skov et al. 2000) and Pacific herring Clupea pallasi (Womble \& Sigler 2006) and anadromous fishes such as salmon Oncorhynchus spp. (Willson \& Halupka 1995, Middlemas et al. 2006) and eulachon Thaleichthys pacificus (Marston et al. 2002, Sigler et al. 2004). A single prey aggregation can attract thousands of individuals and a mixture of predators (Marston et al. 2002), and individual predators may repeatedly return to predictable daily (Irons 1998) and seasonal (Similä et al. 1996) prey aggregations. Diet composition also can be affected by distance from haulouts (Womble et al. 2005), diving ability (Beck et al. 2003) or prey predictability (Gende \& Sigler 2006).

An important mammalian predator in the North Pacific Ocean, the western stock of Steller sea lion Eumetopias jubatus has declined by more than $80 \%$ since the 1960s (Loughlin et al. 1992, Trites \& Larkin 1996), whereas the eastern stock has more than doubled (Pitcher et al. 2007). A diet dominated by less nutritious prey may have contributed to the decline of the western stock (junk food hypothesis) (Alverson 1992, Trites \& Donnelly 2003) and has also been implicated in the population dynamics of other top marine predators (Österblom et al. 2008). Chronically low juvenile survival was likely a primary driver in the Steller sea lion decline (York 1994, Pascual \& Adkison 1994). Adults can meet their daily energy needs eating exclusively low energy prey, but young sea lions cannot and must obtain milk for an extra 1 or $2 \mathrm{yr}$ at the expense of mothers' reproductive rates (Rosen \& Trites 2004, Kumagai et al. 2006, Trites et al. 2006). Low lipid diets appear to negatively affect body composition during periods of inadequate intake (Rosen \& Trites 2004, 2005, Kumagai et al. 2006), and season affects the sea lions' capacity to recover from these episodes (Jeanniard du Dot et al. 2008). Commercial fisheries also may have reduced the quantity of prey and contributed to lower juvenile survival, episodic adult mortality and reduced fecundity or birth rates (Atkinson et al. 2008b).

In our study we address 3 questions regarding Steller sea lion foraging ecology: (1) do Steller sea lions exhibit a flexible foraging strategy and shift diet composition in response to changes in prey availability; (2) do Steller sea lions move between areas as prey becomes available seasonally and is the number present related to the amount of prey available; and (3) are Steller sea lions susceptible to nutritional stress if they rely on less nutritious species? To answer these questions, we studied Steller sea lions and their prey across 3 yr (2001 to 2004) in Frederick
Sound, southeast (SE) Alaska. Frederick Sound is a useful area to learn about Steller sea lion foraging ecology because: (1) several hundred or more sea lions use the area year-round; (2) prey availability and sea lion diet and foraging behavior can be quantified; and (3) study results from this area can be compared to nearby areas used seasonally (Sigler et al. 2004, Womble \& Sigler 2006). We completed multiple measurements, typically on a quarterly basis, including Steller sea lion abundance (aerial surveys), diet (scats), dive behavior (satellite telemetry) and prey availability and caloric density (nearshore, pelagic and demersal fish surveys). We compared seasonal changes in prey abundance and Steller sea lion abundance, as well as diet and foraging behavior. With these data, we tested 3 hypotheses: (1) sea lion diet choice is a function of prey availability; (2) sea lions move to take advantage of times and locations of seasonal prey concentrations; and (3) the number of sea lions present depends on the amount of prey available (numerical response).

\section{MATERIALS AND METHODS}

Study area. The core study area was a $20 \mathrm{~km}$ radius circle centered at the Brothers Islands $\left(56^{\circ} 16^{\prime} \mathrm{N}, 133^{\circ} 52^{\prime} \mathrm{W}\right)$ at the confluence of Stephens Passage and Frederick Sound in SE Alaska, USA, where Steller sea lions use several terrestrial sites (haulouts) to rest and care for young year-round (Fig. 1). This area encompasses a variety of marine habitats (depth ranges between 5 and $480 \mathrm{~m}$ ) that are typical of areas used by foraging sea lions in SE Alaska (Pitcher et al. 2005). Most trips (>90\%) made by juvenile sea lions are $<15 \mathrm{~km}$ from haulouts (Raum-Suryan et al. 2004), while adult females appear to forage within $15 \mathrm{~km}$ during summer and may travel considerably farther during winter (Merrick \& Loughlin 1997). The southern Stephens Passage/northern Frederick Sound study area is 1 of 3 study areas that make up a larger SE Alaska Steller sea lion prey study. The 3 study areas include: (1) an area that sea lions use year-round (Frederick Sound); (2) an area used only during late fall and winter (Lynn Canal, $58^{\circ} 39.0^{\prime} \mathrm{N}, 135^{\circ} 04.0^{\prime} \mathrm{W}$ ) (Womble \& Sigler 2006); and (3) an area used only for a short period during spring (Berners Bay, 58 $45.1^{\prime} \mathrm{N}, 134^{\circ} 58.5^{\prime} \mathrm{W}$ ) (Sigler et al. 2004).

Steller sea lion abundance. Sea lions were counted during monthly aerial surveys of terrestrial sites to determine sea lion abundance in our study area (Fig. 1) from March 2001 to May 2004 (Womble et al. 2009). Counts were made by taking oblique angle photographs from an aircraft passing terrestrial sites, which 


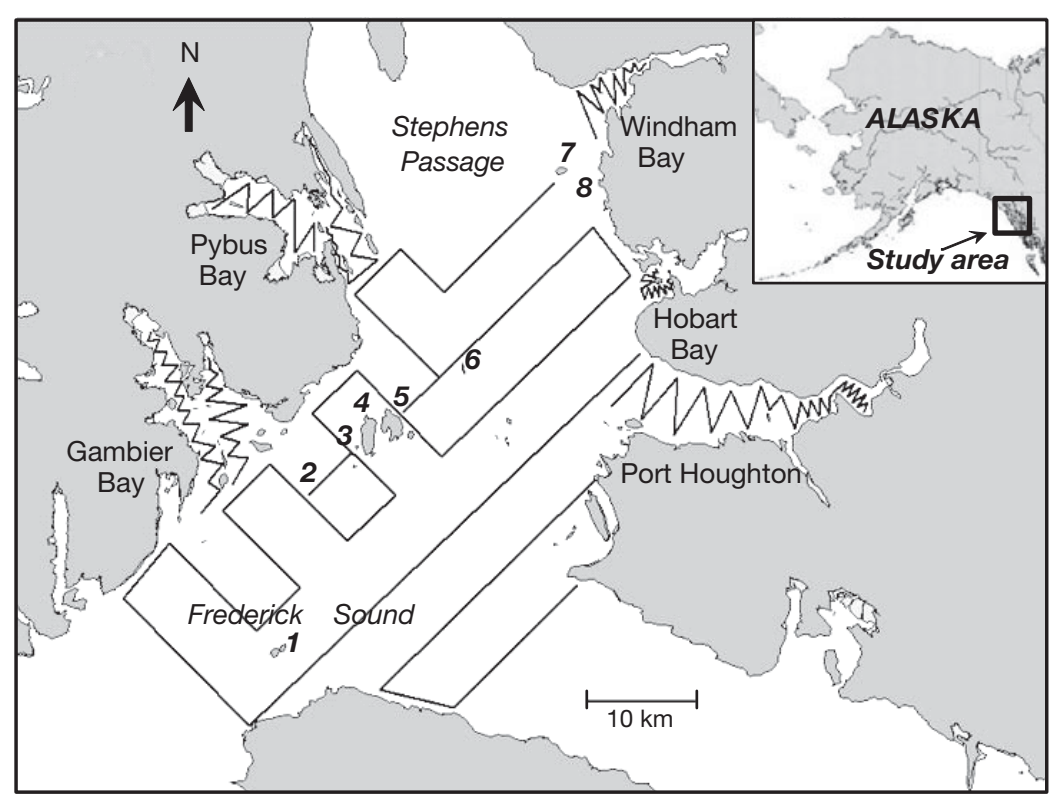

Fig. 1. Acoustic survey transect lines and terrestrial locations (haulouts) where Steller sea lions were counted during aerial surveys. 1: Turnabout Island; 2: Round Rock; 3: Southwest Brothers Island; 4: West Brothers Island; 5: East Brothers Island; 6: Sail Island; 7: Sunset Island; 8: Sunset Point

1 sample collection was less than the recommended minimum sample size of 59 for comparing prey occurrence (Trites \& Joy 2005). Scats were washed through an elutriator (Bigg \& Olesiuk 1990) or a $0.495 \mathrm{~mm}$ sieve. Pacific Identifications identified all hard structures (fish bones, otoliths, cartilaginous parts, lenses and teeth, and cephalopod beaks, lenses and pens) to the lowest possible taxon (Olesiuk et al. 1990, Browne et al. 2002) using a reference collection (all-structures approach). Prey numbers were estimated from counts of hard structures and were adjusted for species-specific recovery rates using species-specific numerical correction factors (Tollit et al. 2003, 2007). Prey sizes were estimated from measurements of hard structures and were adjusted for the observed level of wear using speciesspecific digestion correction factors (Tollit et al. 1997b, 2004).

The overall importance of each prey species (or category) in scat samples

is a standard method for counting Steller sea lions, but not determining age or sex composition (Pitcher et al. 2007). Surveys were conducted from a floatplane (Cessna 206) between 09:00 and 14:00 $\mathrm{h}$ and, when possible, within $3 \mathrm{~h}$ of low tide. The observer/photographer sat in the front seat and photographed sea lions on shore at an oblique angle through an open window from an altitude of 250 to $300 \mathrm{~m}$ at an air speed of 183 to $210 \mathrm{~km} \mathrm{~h}^{-1}$. Photographic images of terrestrial sites were taken using a $35 \mathrm{~mm}$ autofocus camera (Nikon 8008S) with a motor drive equipped with a 70 to $210 \mathrm{~mm}$ zoom lens and a $35 \mathrm{~mm}$ auto-focus digital camera (Nikon D1X) equipped with a 70 to $300 \mathrm{~mm}$ zoom lens. Overlapping images were taken if more than one image was needed to cover the entire site. The clearest image was projected and the sea lions in the image were counted twice by an experienced counter.

Steller sea lion diet. Scat samples were collected $5 \times$ a yr from May 2001 to March 2004 (n = 15 collections) to determine sea lion diet (Tollit et al. 2008). Collections were concurrent with pelagic and nearshore fish surveys (see below). Scat was collected in March, May, June/July, September and December/January. The 4 sites with the greatest sea lion abundance (Southwest Brothers, West Brothers, Sunset and Sail Islands) were visited consistently. Excluding March 2002 (n = 9), sample size averaged 120 scats $(\mathrm{SD}=55$, range $=40$ to 223) for the 4 haulout sites. For these 9 samples, only was expressed using: (1) frequency of occurrence (FO, \%) (Hyslop 1980); (2) reconstructed biomass (BR, \%) (Hammond \& Rothery 1996); (3) energetic contribution (EC, \%) (Vollenweider et al. 2006); and (4) index of relative importance (IRI) (Hyslop 1980), which uses a composite of prey number, FO and BR. Biomass was reconstructed by combining prey numbers and sizes, which were converted to biomass using length-weight relationships. EC was computed from reconstructed biomass and species-specific and seasonal energy density values (Vollenweider et al. 2006). Biomass reconstruction and energy contribution calculations used a weighted or variable method (Lance et al. 2001) and pooled scats for comparability with previous diet studies in the region (Vollenweider et al. 2006, Womble \& Sigler 2006). Diet diversity also was calculated to compare across studies (Merrick et al. 1997, Sinclair \& Zeppelin 2002, Womble \& Sigler 2006, Trites et al. 2007). Chi-squared tests on occurrence data were used to assess differences in diet for the 9 most important prey categories (overall $\mathrm{FO} \geq 5 \%$ ). The dominant prey species, walleye pollock Theragra chalcogramma, also was analyzed by size category (young-of-the-year [YOY]: $<20 \mathrm{~cm}$; juvenile: 20 to $34 \mathrm{~cm}$; adult: $\geq 34 \mathrm{~cm}$ ) (Tollit et al. 2004).

Captive feeding studies with Steller sea lions have shown that an all-structures approach reliably detects meals of small $(10 \mathrm{~cm})$ prey, although the proportion recovered is less than that for larger prey, hence the 
need for correction factors (Tollit et al. 2007). Adult gadids have relatively robust skeletal structures with a high likelihood of being recovered in scats, but they also have a greater propensity of being regurgitated (Tollit et al. 2003), as do large cephalopod beaks. Comparisons of hard part identifications with molecular genetic techniques to identify prey from soft tissue in scats tissue indicated the former technique had missed $\sim 20 \%$ of recent meals (Tollit et al. 2009). These consisted mainly of salmonids, flatfish, elasmobranches and cephalopods, amounting to $10-15 \%$ increases in individual occurrences. Overall, occurrence indices provide a valuable comparative index related to the number of animals eating a prey type. They likely overestimate the relative importance of small or trace prey, while, conversely, biomass-related indices (BR and EC) may often overestimate the importance of large prey (Laake et al. 2002), especially when using a weighted approach and/or small numbers of scats.

A bioenergetic model (Winship et al. 2002) was used to estimate the biomass of prey consumed by Steller sea lions during each of the 5 scat sampling periods. Inputs included sea lion abundance, diet composition and energy content for our study area, and estimated age- and sex-specific energy requirements by date (Winship et al. 2002). A stable age structure was assumed (Winship et al. 2002). The counts were adjusted for the unobserved individuals because sea lions were counted while on land and did not include individuals in the water. The proportion of time Steller sea lions spend ashore varies with time of yr and age/sex classes (lower in winter than summer, lower for juveniles than adults overall) and ranges from 10 to $63 \%$ (Holmes et al. 2007). We used the mid-point of this range (37\%), so that a count of 370 individuals ashore implied 1000 individuals total. Energy requirements were computed per individual and then multiplied by the maximum sea lion abundance for that sampling period. The values per individual ranged from $67613 \mathrm{~kJ} \mathrm{~d}^{-1}$ during June/July to $97568 \mathrm{~kJ} \mathrm{~d}^{-1}$ during May. Total food consumption was calculated by allocating total energy requirements based on energy content and composition of the biomass-reconstructed diet.

Prey selection was assessed by the odds ratio (O) (Fleiss 1981): $O=\left(p_{1} \times q_{2}\right) /\left(p_{2} \times q_{1}\right)$, where $p_{1}$ is the proportion of the diet consisting of a particular prey item, $\mathrm{p}_{2}$ is the relative abundance as a proportion of this prey item in the environment, $\mathrm{q}_{1}$ is the proportion of the diet contributed by all other prey items and $\mathrm{q}_{2}$ is the relative abundance of all the other prey items in the environment. Odds ratios were transformed logarithmically (base 10). Positive values indicate prey that were selected and negative values indicate potential prey that were ignored. Prey size selection was assessed by comparing size frequencies from scats to size frequen- cies from prey abundance surveys using the Kolmogorov-Smirnov statistical test to determine if the 2 distributions differed significantly.

Steller sea lion dive behavior. Juvenile sea lions were captured throughout SE Alaska and tagged to monitor their movement. Juveniles were tagged because chronically low juvenile survival likely was a primary driver in the decline of the western stock (York 1994, Pascual \& Adkison 1994) and no method for tagging adults is considered safe enough for permit approval. Although these tagging results apply only to juveniles, studies of the ontogeny of dive performance show that by $1.5 \mathrm{yr}$ of age, juveniles are capable of sustained periods of long dives. Depths and durations of their dives are similar to adult females (Pitcher et al. 2005) and juveniles and subadults dive to similar depths and durations (Rehberg and Burns 2008). A total of 111 individuals was fitted with satellite dive recorders (SDR, Wildlife Computers) that relayed point location estimates, on-land/ at-sea cycles and summarized dive characteristics (Pitcher et al. 2005). For each individual, we linked the on-land/at-sea data to location estimates and used this information to identify which ones were present within the Frederick Sound study area during $6 \mathrm{wk}$ windows centered around scat collections (median dates). Six juvenile sea lions captured during 5 to 15 May 2001 were present in the study area during the May and June/July 2001 scat sampling periods, and 4 juveniles captured during 15 to 20 November 2002 were present during the December 2002 scat sampling period. Their estimated ages at tagging ranged from 17 to $29 \mathrm{mo}$. Some Steller sea lions are weaned before or on their first birthday, while others continue to suckle until their second birthday or beyond (Pitcher \& Calkins 1981, Trites \& Porter 2002, Trites et al. 2006). Thus some of these tagged individuals may still have been suckling and dependent on their mother for some portion of their nutrition.

We calculated the proportion of time spent submerged below $4 \mathrm{~m}$ for each $6 \mathrm{~h}$ summary period provided by the SDRs. We identified whether summary periods were primarily in daylight or darkness using civil twilight (solar angle $=-6^{\circ}$ ) of each date in the study area as the threshold. We also determined the maximum depth reached per $24 \mathrm{~h}$ day by each sea lion. Using a generalized linear model (GLM), we examined the effect of season (May-June vs. December) and time of day (day vs. night) and their interaction on time submerged, including individual animal as a random effect. Time submerged was arcsine-root transformed to improve normality, post hoc tests had Bonferroni correction and significance was set at $\mathrm{p}<0.05$.

Prey availability. Prey surveys were conducted in 3 major habitat types in Frederick Sound: pelagic, 
demersal and nearshore habitats. Acoustic surveys were conducted quarterly from May 2001 to March 2004 to estimate abundance of pelagic prey. Surveys were conducted during March, May, September and December (except that the December 2003 survey was postponed to January 2004). Prey availability was estimated using a portable $38 \mathrm{kHz}$ Simrad split beam echosounder with a $12^{\circ}$ beam angle towed beside a vessel at $11 \mathrm{~km} \mathrm{~h}^{-1}$, or a $38 \mathrm{kHz}$ Simrad split beam echosounder with a $7^{\circ}$ beam angle transducer attached to the hull of a vessel traveling at $15 \mathrm{~km} \mathrm{~h}^{-1}$. Acoustic transect routes (Fig. 1) were geo-referenced using a Garmin GPS with $\pm 10 \mathrm{~m}$ accuracy. All surveys began in the morning after daybreak and concluded before dark to account for diel variation in acoustic density estimates (Huse \& Korneliussen 2000) and to facilitate observations of foraging sea lions while collecting acoustic data. Midwater trawls were deployed to identify acoustic targets in the echograms and to collect fork length (FL), weight and species composition data.

The acoustic data were analyzed with an echo-integrator that summed the returning echoes from fish observed beneath the vessel. Acoustic data were classified by $183 \mathrm{~m}$ length intervals and $10 \mathrm{~m}$ depth intervals and corrected for instrument calibration using the echo-integration software SonarData Echoview. The output of acoustic scattering (nautical area scattering coefficient [NASC]) was used to compute fish density (MacLennan \& Simmonds 1992). Target strength (TS) refers to the acoustic reflectivity of a single echo or fish and depends on length $(\mathrm{L}$, in $\mathrm{cm})$ : TS $=20$ $\log _{10} \mathrm{~L}+b$ (MacLennan \& Simmonds 1992); for walleye pollock, $b=-66$ (Traynor 1996), for Pacific hake Merluccius productus, $b=-68$ (Traynor 1996) and for herring, $b=-65.4$ (Ona 2003). In addition, Pacific herring acoustic estimates were adjusted for depth compression of the air bladder (Ona 2003) and acoustic shadowing (Zhao \& Ona 2003, Sigler \& Csepp 2007). Hake and pollock sometimes were found in mixed concentrations; the mixed-species NASC was partitioned to species based on each species' average acoustic backscatter and proportional weight in midwater trawl catches (MacLennan \& Simmonds 1992, their Eq. 8.8), with equal weight given to the proportions in each catch (MacLennan \& Simmonds 1992, their Eq. 8.9). Average fish density was computed by substrata to account for differences in fish density within the survey area. The substrata consisted of the individual bays and the open water at the confluence of Frederick Sound and Stephens Passage. Fish biomass was computed by multiplying average fish density in weight by the aerial size of the substrata.

Longline surveys were conducted during September 2003, February/March 2004 and May 2004 to estimate seasonal trends in relative abundance of demersal prey. Standardized longline gear was used, with \#14/0 Mustad hooks spaced $1.6 \mathrm{~m}$ apart and baited with chopped squid (mantle length averaging $16.5 \mathrm{~cm}, 2$ to 3 baits per squid including tentacles). The groundline was $0.87 \mathrm{~cm}$ diameter and gangions were \#66 thread and $25 \mathrm{~cm}$ tied length. Fifteen longline sets were completed during each seasonal survey. The location of the first station was randomly chosen, and then the remaining stations were systematically located to cover the survey area. The same 15 locations were sampled each survey period. Depths from 53 to $397 \mathrm{~m}$ were sampled. Catch, fork length, weight and effort (number of hooks) data were recorded. Relative abundance was inferred by computing catch (numbers and weight) per 1000 hooks by species.

Nearshore areas were surveyed for prey in winter (March 2002, 2003 and 2004) and summer (July 2001, 2002 and 2003) to estimate seasonal trends in relative abundance of nearshore prey species around the Brothers Islands (Thedinga et al. 2006). Beach seining, jigging and a remotely operated vehicle (ROV) were used for surveys. Intertidal and subtidal areas $(<115 \mathrm{~m}$ deep, $<350 \mathrm{~m}$ from shore) were sampled. Depths $<5 \mathrm{~m}$ were sampled by beach seine at 14 sites, and depths from 5 to $115 \mathrm{~m}$ were sampled by jigging at 18 sites. Captured fish were counted and a subsample of most species was measured for fork length; large catches were estimated gravimetrically (Thedinga et al. 2006). The ROV surveyed depths from 1 to $85 \mathrm{~m}$ (limit of umbilical cord) at 11 sites for fish not captured by jigging or seining.

Whole fish were frozen during pelagic, nearshore and demersal surveys for measurement of caloric content and protein and fat composition using standard laboratory procedures (Vollenweider et al. 2006). Season- and species-specific values of energy density were multiplied by quarterly biomass measurements from the pelagic surveys to determine available energy per quarter. Available energy was computed only for pelagic prey because biomass was estimable for the acoustic survey, whereas the nearshore and demersal surveys only indexed abundance. Available prey energy was compared to estimates of individual sea lion energy demands per day (annual average of $79464 \mathrm{~kJ} \mathrm{~d}^{-1}$ per individual) (Sigler et al. 2004), which were derived using bioenergetic models for Steller sea lions (Winship et al. 2002).

Steller sea lion numerical response. We estimated the numerical response of Steller sea lions to variations in prey abundance. A numerical response provides a measure of how Steller sea lion populations will respond to changes in fishing or how ocean conditions modify prey fields. Counts of Steller sea lions were regressed against nutritional energy of pelagic prey. 
Both variables were log-transformed to meet the assumption that they were obtained from normal populations. Data from a year-round study at Lynn Canal (Sigler \& Csepp 2007) were added to the Frederick Sound data because the Lynn Canal prey and sea lion abundances varied much more and provided more contrast to detect a numerical response. The numerical response was estimated based on pelagic biomass, but not demersal or nearshore biomass which were indexed (catch rates). Steller sea lions counts were adjusted for time spent ashore (37\%).

\section{RESULTS}

\section{Steller sea lion abundance}

Sea lions occupied terrestrial sites $(n=8)$ in the study area throughout the yr (Table 1). The total number of sea lions of all age classes observed ashore during surveys $(\mathrm{n}=39$ ) ranged from 669 (February 2002) to 2374 (August 2002), excluding months when one or more of the 4 most attended sites (Southwest Brothers, West Brothers, Sunset and Sail Islands) were not surveyed

Table 1. Eumetopias jubatus. Number of Steller sea lions counted at terrestrial sites during aerial surveys of Frederick Sound, SE Alaska. I. = island, NC: no count

\begin{tabular}{|c|c|c|c|c|c|c|c|c|c|}
\hline $\begin{array}{l}\text { Year and } \\
\text { month }\end{array}$ & $\begin{array}{l}\text { Southwest } \\
\text { Brothers I. }\end{array}$ & $\begin{array}{c}\text { West } \\
\text { Brothers I. }\end{array}$ & $\begin{array}{c}\text { East } \\
\text { Brother I. }\end{array}$ & $\begin{array}{l}\text { Turn- } \\
\text { about I. }\end{array}$ & $\begin{array}{l}\text { Sunset } \\
\text { Island }\end{array}$ & $\begin{array}{c}\text { Sail } \\
\text { Island }\end{array}$ & $\begin{array}{c}\text { Round } \\
\text { Rock }\end{array}$ & $\begin{array}{c}\text { Sunset } \\
\text { Point }\end{array}$ & Total \\
\hline \multicolumn{10}{|l|}{2001} \\
\hline March & $\mathrm{NC}$ & $\mathrm{NC}$ & $\mathrm{NC}$ & 28 & 61 & 41 & 30 & $\mathrm{NC}$ & 160 \\
\hline April & 168 & 0 & 179 & 1 & 218 & 90 & 16 & $\mathrm{NC}$ & 672 \\
\hline May & 489 & 0 & 0 & 0 & 558 & 150 & 6 & $\mathrm{NC}$ & 1203 \\
\hline June & 528 & 0 & 0 & 0 & 478 & 316 & 1 & $\mathrm{NC}$ & 1323 \\
\hline July & 361 & 0 & 0 & 0 & 706 & 5 & 0 & $\mathrm{NC}$ & 1072 \\
\hline August & 1283 & 0 & 0 & 0 & 19 & 644 & 0 & 0 & 1946 \\
\hline September & 526 & 8 & 4 & 12 & 120 & 601 & 3 & 0 & 1274 \\
\hline October & 361 & 421 & 0 & 181 & 62 & 387 & 42 & 0 & 1454 \\
\hline November & $\mathrm{NC}$ & $\mathrm{NC}$ & 0 & $\mathrm{NC}$ & $\mathrm{NC}$ & $\mathrm{NC}$ & $\mathrm{NC}$ & $\mathrm{NC}$ & 0 \\
\hline December & $\mathrm{NC}$ & $\mathrm{NC}$ & 0 & $\mathrm{NC}$ & $\mathrm{NC}$ & $\mathrm{NC}$ & $\mathrm{NC}$ & $\mathrm{NC}$ & 0 \\
\hline \multicolumn{10}{|l|}{2002} \\
\hline January & 214 & 266 & 0 & 137 & 31 & 48 & 36 & 206 & 938 \\
\hline February & 270 & 0 & 15 & 76 & 77 & 59 & 37 & 135 & 669 \\
\hline March & 364 & 0 & 0 & 124 & 347 & 32 & 57 & 108 & 1032 \\
\hline April & 269 & 0 & 0 & 21 & 343 & 103 & 45 & 118 & 899 \\
\hline May & 710 & 0 & 0 & 0 & 342 & 160 & 13 & 1 & 1226 \\
\hline June & 741 & 0 & $\mathrm{NC}$ & 0 & 566 & 7 & 0 & 0 & 1314 \\
\hline July & $\mathrm{NC}$ & 0 & 0 & 0 & $\mathrm{NC}$ & 3 & 6 & 0 & 9 \\
\hline August & 1752 & 0 & 0 & 0 & 8 & 614 & 0 & 0 & 2374 \\
\hline September & 481 & 0 & 0 & 0 & 8 & 1124 & 21 & 0 & 1634 \\
\hline October & 684 & 129 & $\mathrm{NC}$ & 18 & 267 & 1110 & 63 & 0 & 2271 \\
\hline November & 291 & 172 & 0 & 57 & 45 & 222 & 41 & 48 & 876 \\
\hline December & 316 & 291 & 0 & 187 & 54 & 191 & 50 & 15 & 1104 \\
\hline \multicolumn{10}{|l|}{2003} \\
\hline January & 534 & 276 & 0 & 170 & 178 & 163 & 44 & 121 & 1486 \\
\hline February & 277 & 66 & 0 & 45 & 280 & 124 & 44 & 0 & 836 \\
\hline March & 496 & 0 & 0 & 48 & 600 & 75 & 108 & 66 & 1393 \\
\hline April & 98 & 2 & 0 & 0 & 318 & 156 & 114 & 5 & 692 \\
\hline May & 759 & 3 & 4 & 0 & 611 & 124 & 8 & 0 & 1509 \\
\hline June & 1126 & 0 & 0 & 0 & 522 & 45 & 0 & 0 & 1693 \\
\hline July & 1483 & 0 & 0 & 0 & 8 & 248 & 0 & 0 & 1739 \\
\hline August & 1457 & 0 & 0 & 3 & 0 & 404 & 0 & 0 & 1864 \\
\hline September & 911 & 0 & 0 & 0 & 40 & 1297 & 3 & 0 & 2251 \\
\hline October & 735 & 0 & 0 & 120 & 177 & 274 & 39 & 0 & 1345 \\
\hline November & 620 & 308 & $\mathrm{NC}$ & 308 & 165 & 313 & 63 & 0 & 1777 \\
\hline December & 402 & 451 & 0 & 311 & 259 & 248 & 54 & 0 & 1725 \\
\hline \multicolumn{10}{|l|}{2004} \\
\hline January & 311 & 260 & 0 & 179 & 372 & 100 & 38 & 0 & 1260 \\
\hline February & 392 & 104 & 0 & 162 & 518 & 118 & 94 & 0 & 1388 \\
\hline March & 392 & 0 & 0 & 95 & 391 & 161 & 81 & 0 & 1120 \\
\hline April & 127 & 0 & 0 & 0 & 525 & 85 & 35 & 0 & 772 \\
\hline May & 509 & 0 & 0 & 9 & 508 & 1 & 3 & 0 & 1030 \\
\hline
\end{tabular}


due to bad weather. Average abundance was highest during August (2061) and lowest during April (759). Terrestrial sites at Southwest Brothers, Sunset and Sail Islands were occupied throughout the yr. Steller sea lions were most abundant at Southwest Brothers Island, which was occupied by up to 1752 sea lions (August 2002). In contrast, other terrestrial sites were occupied seasonally (Turnabout Island and Round Rock during fall, winter, and spring; West Brothers Island during fall and winter). Sea lions also were observed infrequently at Walter Island in Port Houghton near Frederick Sound (December 2002, October and November 2003). Most sea lions counted on the haulouts likely were juveniles and adult females. Counts from a year-long (July 2004 to July 2005) ground-based study at Southwest Brothers Island found adult females (40\%), juveniles and pups (55\%) and bulls and subadult males (5\%) (Marcotte 2006).

\section{Steller sea lion diet}

A total of 59 prey species/categories was identified from scat samples collected during May 2001 to March 2004 ( $\mathrm{n}=1640$ scats with remains, 9739 identified prey items). Nine species occurred in at least $5 \%$ of scat samples (Table 2). Walleye pollock dominated prey occurrence $(\mathrm{FO}=95 \%$ ), followed by Pacific herring, Pacific hake and arrowtooth flounder Atheresthes stomias (FO $=20$ to $40 \%$ ), and skate (Rajidae), cephalopods, Pacific cod Gadus macrocephalus, salmon and rockfish Sebastes spp. (FO = 5 to $15 \%)$. Pollock (BR = $39 \%$ ) also dominated prey biomass (particularly juveniles, $\mathrm{BR}=22 \%$ ), followed by arrowtooth flounder and skate $(B R=11$ to $12 \%)$, and salmon, cod, herring and hake ( $\mathrm{BR}=5$ to $7 \%$ ). Each of these 7 species also contributed $\geq 5 \%$ of estimated energetic consumption. For IRI, pollock ranked first, followed by herring, arrowtooth flounder, hake, skate and salmon. Pollock occurrence was consistent year-round (>91\%, coefficient of variation $[\mathrm{CV}]=2 \%$ ), whereas salmon occurrence increased each September (to $21-35 \%, C V=100 \%$, Fig. 2). Temporal variability of the other key species (FO $\geq 5 \%$ ) was intermediate ( $\mathrm{CV}=47$ to $73 \%$ ), with all species but rockfish showing statistically significant seasonal effects. A wide size range of prey (3 to $111 \mathrm{~cm})$ was consumed, but most $(78 \%)$ were 10 to $35 \mathrm{~cm}$ (Figs. 3 \& 4). The heaviest individual prey was an $~ 8 \mathrm{~kg}$ skate.

The number of prey species per scat sample averaged $2.5 \pm 1.7(\mathrm{SD})$ and ranged from 1 to 14 species. About one-third of the recovered scats contained only one species, which was predominantly pollock (94\%). No other prey species exceeded $3 \%$ as the sole species. As a result, pollock occurred with 1.6 other species on average, while the remaining key species occurred with between 2.8 (herring) and 3.7 (skate) other species on average. Herring occurred on its own in just $1.3 \%$ of cases, co-occurring with pollock in $95 \%$ of cases, with hake in $37 \%$ of cases and with arrowtooth flounder in $28 \%$ of cases. About $28 \%$ of the recovered scats contained 2 species. In $92 \%$ of the cases, one of the 2 species was pollock.

We computed diet (Shannon's index) diversity 3 different ways to compare our results to those from recent publications on Steller sea lion diet (prey species with FO > 5\%, Womble \& Sigler 2006; prey family FO, Sinclair \& Zeppelin 2002; taxonomic grouping and trophic

Table 2. Key prey species (frequency of occurrence $[\mathrm{FO}] \geq 5 \%$ ) consumed by Steller sea lions in Frederick Sound, SE Alaska, based on 1640 scats containing hard remains. Estimates for walleye pollock were additionally partitioned by size class (in italics) and $\mathrm{FO}$ was modified $\left(\mathrm{FO}_{\mathrm{mod}}\right.$ ) to total $100 \%$ for comparison across indices. Biomass reconstruction (BR) and energetic contribution (EC) indices were calculated based on number (N) of fish (adjusted for species-specific recovery rates), prey size estimates (adjusted for observed level of wear of hard structures) and energetic density values. The index of relative importance (IRI) ranks prey based on a composite of N, FO and BR. P-values are based on chi-square analyses of prey occurrence counts that tested for season and year effects

\begin{tabular}{|c|c|c|c|c|c|c|c|c|c|c|}
\hline \multirow[t]{2}{*}{ Species category } & \multirow[t]{2}{*}{$\mathrm{N}$} & \multirow[t]{2}{*}{$\mathrm{FO}$} & \multirow[t]{2}{*}{$\mathrm{FO}_{\text {mod }}$} & \multirow[t]{2}{*}{$\mathrm{BR}$} & \multirow[t]{2}{*}{$\mathrm{EC}$} & \multirow[t]{2}{*}{ IRI } & \multicolumn{2}{|c|}{ Season } & \multicolumn{2}{|c|}{ Year } \\
\hline & & & & & & & $\chi^{2}$ & $\mathrm{p}$ & $\chi^{2}$ & $\mathrm{p}$ \\
\hline Pollock overall & 5817 & 95.4 & 37.8 & 39.1 & 33.5 & 1 & 0.2 & 0.99 & 0.4 & 0.82 \\
\hline Young-of-the-year & 1238 & 30.7 & - & 2.4 & 2.0 & - & & & & \\
\hline Juvenile & 3678 & 76.5 & - & 22.4 & 18.9 & - & & & & \\
\hline Adult & 901 & 43.1 & - & 14.3 & 12.6 & - & & & & \\
\hline Pacific herring & 1277 & 32.9 & 13.0 & 5.7 & 9.2 & 2 & 35.3 & $<0.001$ & 20.2 & $<0.001$ \\
\hline Pacific hake & 532 & 27.1 & 10.7 & 5.3 & 5.3 & 4 & 36.5 & $<0.001$ & 6.5 & 0.04 \\
\hline Arrowtooth flounder & 376 & 21.3 & 8.5 & 12.2 & 17.1 & 3 & 66.3 & $<0.001$ & 13.9 & $<0.001$ \\
\hline Skate spp. & 235 & 14.3 & 5.7 & 11.2 & 11.7 & 5 & 168.6 & $<0.001$ & 1.3 & 0.52 \\
\hline Cephalopod spp. & 299 & 13.9 & 5.5 & 1.9 & 1.8 & 8 & 62.0 & $<0.001$ & 31.2 & $<0.001$ \\
\hline Pacific cod & 263 & 12.5 & 4.9 & 6.4 & 5.3 & 7 & 34.8 & $<0.001$ & 12.8 & 0.002 \\
\hline Salmonid spp. & 236 & 12.0 & 4.7 & 7.3 & 6.7 & 6 & 168.6 & $<0.001$ & 1.3 & 0.52 \\
\hline Rockfish spp. & 78 & 4.7 & 1.9 & 2.2 & 2.7 & 9 & 7.7 & 0.10 & 19.9 & $<0.001$ \\
\hline
\end{tabular}




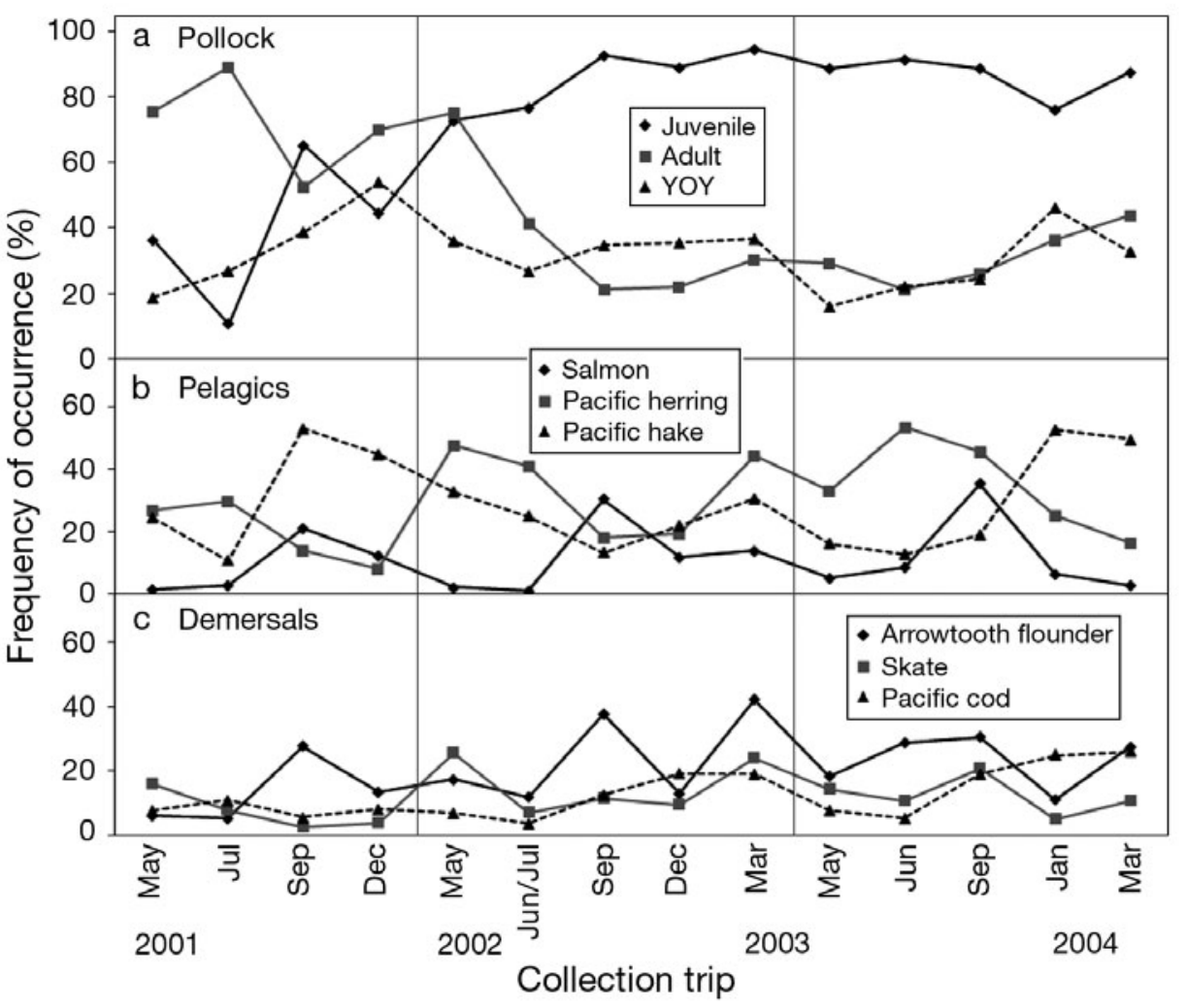

Fig. 2. Temporal changes in the occurrence of key species in Steller sea lion diet in Frederick Sound, SE Alaska (May 2001 to March 2004). (a) Walleye pollock (young-of-the-year [YOY]: $<20 \mathrm{~cm}_{\text {; }}$ juvenile: $20-34 \mathrm{~cm}$; adult: $\geq 34 \mathrm{~cm}$ ), (b) pelagic prey (salmon sp., Pacific herring and Pacific hake) and (c) demersal prey (arrowtooth flounder, skate and Pacific cod). Note that the frequencies of occurrences do not sum to $100 \%$ and that scats can contain the remains of one or more species (or size class of pollock) level, Trites et al. 2007). Steller sea lions seem to need a variety of prey available (Merrick et al. 1997). Diet diversity sensu Womble \& Sigler (2006) was 2.3 overall. Seasonal diversity was highest in March and September (2.4 to 2.5), with lower values in December, May and June/July (1.8 to 2.1). Diversity values sensu Sinclair \& Zeppelin (2002) were 2.3 during May to September and 2.6 during October to April. Diet diversity sensu Trites et al. (2007) was 3.5 overall and also lower in December, May and June/July (2.9 to 3.1) than March and September (4.0 to 4.1) (Tollit et al. 2008).

Estimated average prey consumption for all sea lions in Frederick Sound was $2200 \mathrm{t} \mathrm{mo}^{-1}$, and estimated daily individual consumption was $18.7 \mathrm{~kg}$. Monthly consumption varied seasonally and was lowest in June/July (1700 t) and highest in September (2600 t). The seasonal variation reflected not only variation in sea lion abundance, but also higher proportions of energy-dense prey such as herring during summer. Monthly consumption of pollock (range $=800$ to $1200 \mathrm{t}$ ) and herring (70 to 190 t) both peaked in May, while consumption of hake (80 to $220 \mathrm{t}$ ) peaked in December. Consumption of salmon was 400 to $420 \mathrm{t}$ in September, equivalent to $\sim 27000$ adult pink salmon. Although monthly prey consumption appears large $\left(2200 \mathrm{t} \mathrm{mo}^{-1}\right)$, it represents a small portion of the prey that was available. The number of daily energy rations available from pelagic prey averaged 550000 per sea lion.

\section{Juvenile Steller sea lion dive behavior}

Juvenile Steller sea lions during May-July spent a greater proportion of their time submerged at night (0.66) than during daylight $\left(0.43, F_{1}=19.095, \mathrm{p}<0.001\right)$. During December, the proportion of time submerged was similar during daytime and nighttime $\left(F_{1}=2.466\right.$, $\mathrm{p}=0.117$ ). The only significant seasonal effect occurred during nighttime, when sea lions spent more time submerged during May-July (0.66) than December (0.36, $\left.F_{1}=29.825, \mathrm{p}<0.001\right)$. Maximum daily depths reached by sea lions averaged $85 \pm 42 \mathrm{~m}$ (SD) during December and $99 \pm 29 \mathrm{~m}$ during May-July. The average of maximum dive depths reached by individuals was $215 \pm$ $145 \mathrm{~m}$ (maximum $=420)$ during December and $195 \pm$ $41 \mathrm{~m}$ (maximum = 244) during May-July.

\section{Prey availability}

\section{Pelagic species}

Twelve acoustic surveys were conducted between May 2001 and March 2004, totaling $5437 \mathrm{~km}$ of standard acoustic transects and including 319 midwater trawl tows. The largest midwater trawl catches by weight were pollock, hake and herring. Acoustic estimates of abundance were completed for these 3 species because 


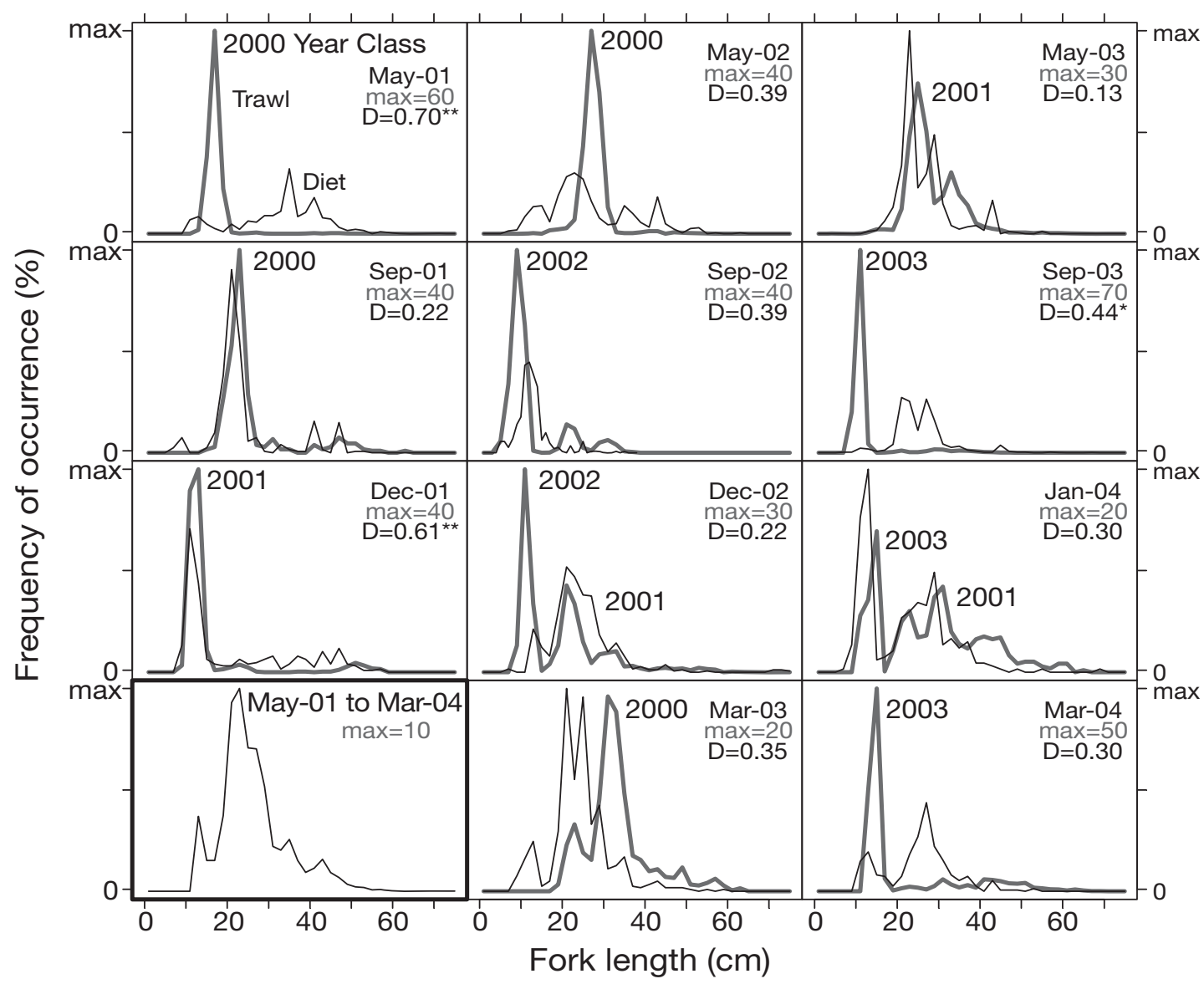

Fig. 3. Theragra chalcogramma. Size frequencies of walleye pollock found in the diet of Steller sea lions overall (panel in lower left corner) and compared with sizes found in concurrent midwater trawl sampling in Frederick Sound, SE Alaska. The dominant yr class (yr of recruitment) associated with trawl surveys is indicated in each period. max: maximum frequency of occurrence; D: Kolmogorov-Smirnov statistical result with significance levels of $p<0.05\left({ }^{*}\right)$ and $p<0.01\left({ }^{* *}\right)$ indicated. Three of the 12 sets of compared frequency distributions differed significantly

the catches consistently confirmed delineations of these species in the echograms. Other large catches by weight (>100 kg) or number (>1000) were jellyfish (Scyphozoa), northern lampfish Stenobrachius leucopsarus, smooth lumpsucker Aptocyclus ventricosus, eulachon, Pacific glass shrimp Pasiphaea pacifica, northern shrimp Pandalus borealis and northern smoothtongue Leuroglossus schmidti. These species plus squid (Teuthida) and Pacific viperfish Chauliodus macouni were widely caught (FO > $10 \%$ ). Pollock were most abundant (average biomass of $9057 \mathrm{t})$, followed by hake (1715 t) and herring (1176 t) (Table 3). Pollock abundance differed seasonally ( $\mathrm{p}=$ 0.03 ) and annually ( $p=0.02)$ (2-way ANOVA, df = 11). In this case, yr refers to survey yr (e.g. survey yr 1 encompasses May 2001 to March 2002). Pollock abundance was higher in May and September than December and March for each survey yr. Pollock abundance was higher in the 2nd survey yr than in the 1st and 3rd survey yr for each season. Neither season nor yr differed for hake or herring (2-way ANOVA, df = 11, p > 0.25).

\section{Demersal species}

Three longline surveys were conducted between September 2003 and May 2004, totaling 16815 hooks. The largest catches were Pacific halibut Hippoglossus stenolepis, followed by Pacific cod and sablefish Anoplopoma fimbria (Table 4). Arrowtooth flounder and sandpaper skate Bathyraja interrupta were also caught frequently. These species together comprised $95 \%$ of the total catch by weight for all 3 survey periods combined. Of these 5 species, relative abundance differed seasonally for arrowtooth flounder $(\mathrm{p}=0.01)$, Pacific cod $(\mathrm{p}<0.01)$ and sablefish $(\mathrm{p}<$ 0.01) (2-way ANOVA, df = 2). Arrowtooth flounder were most abundant during September, Pacific cod during February and May and sablefish during September. For all species combined, relative abundance was $40 \%$ higher in February than September or May, but this difference was not statistically significant $(\mathrm{p}=0.23)$. 

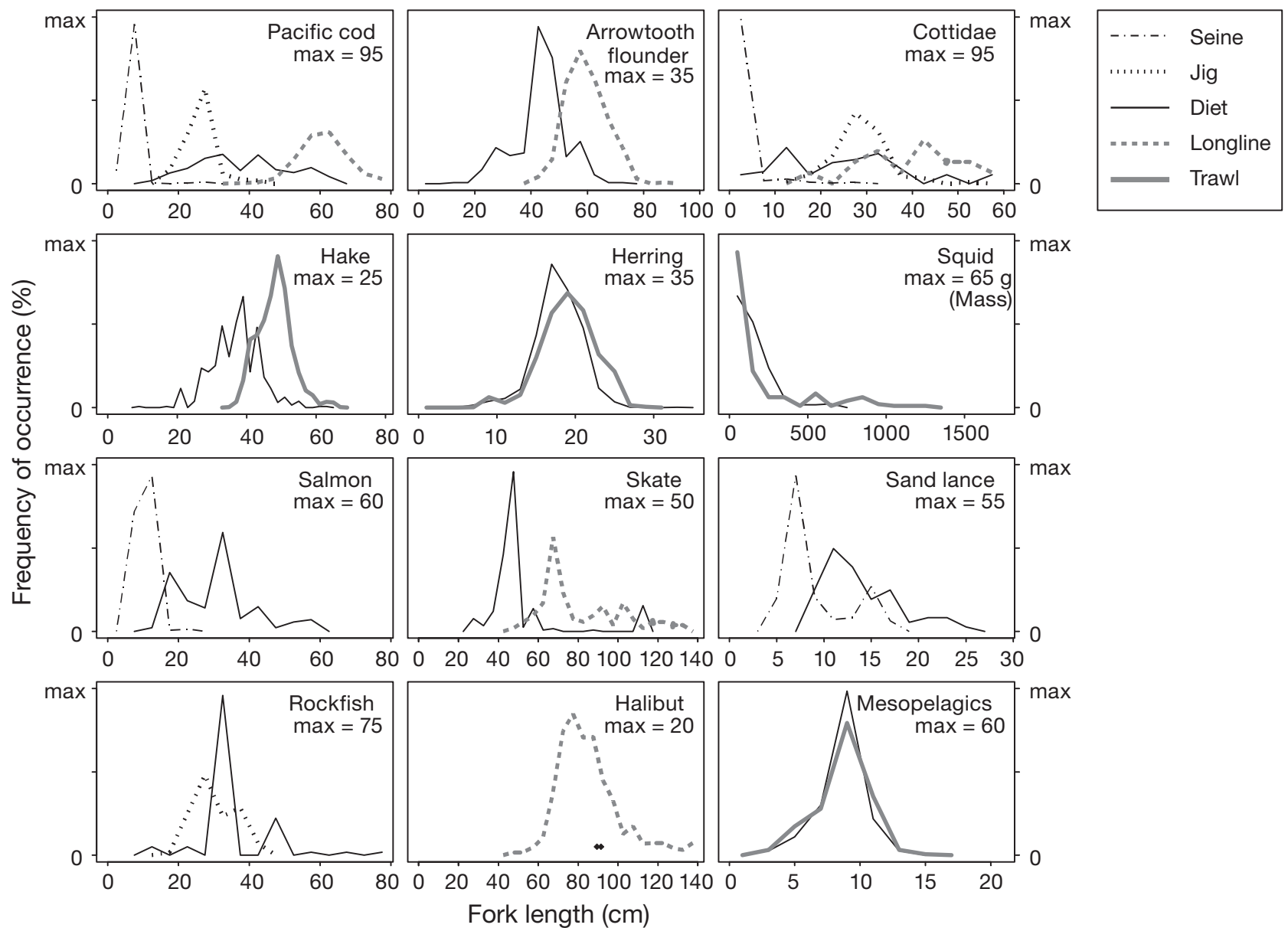

Fig. 4. Size frequencies of several species found in the diet of Steller sea lions compared with sizes found in concurrent midwater trawl, seine, jig and longline surveys of Frederick Sound, SE Alaska. max: maximum frequency of occurrence. Squid measurements are mantle length and black diamonds represent single fish consumed by Steller sea lions

\section{Nearshore species}

In summer, a total of 39 beach seine hauls yielded 187613 fish representing 37 species (Thedinga et al. 2006). Total catch was dominated by pollock $(85 \%)$, Pacific herring and Pacific sand lance Ammodytes hexapterus. In winter, 987 fish were captured in 40 beach seine hauls representing 24 species; pink salmon Oncorhynchus gorbuscha fry occurrence was $60 \%$. Seine catch rates were higher during summer than winter (GLM ANOVA of log-transformed values, $\mathrm{p}<0.05)$. Catch varied by yr, especially in summer, because of strong pollock (notably 2001, 2003) and herring (2003) yr classes. A total of 363 fish representing 22 species was captured by jigging; catches were dominated by armorhead sculpin Gymnocanthus

Table 3. Merluccius productus, Clupea pallasi and Theragra chalcogramma. Acoustic estimates of abundance (t) of Pacific hake, Pacific herring and walleye pollock during surveys in Frederick Sound, SE Alaska, by yr and mo. p-values for season and year effects are based on a 2-factor ANOVA with no replication

\begin{tabular}{|c|c|c|c|c|c|c|c|c|c|c|c|c|c|c|c|c|c|}
\hline \multirow[t]{2}{*}{ Species } & \multicolumn{3}{|c|}{2001} & \multicolumn{4}{|c|}{2002} & \multicolumn{3}{|c|}{2003} & \multicolumn{2}{|c|}{2004} & \multirow[t]{2}{*}{ Mean } & \multirow[t]{2}{*}{$\mathrm{SD}$} & \multirow[t]{2}{*}{$\mathrm{CV}$} & \multirow{2}{*}{\multicolumn{2}{|c|}{$\begin{array}{l}\text { Season Year } \\
\text { effect effec }\end{array}$}} \\
\hline & May & Sep & Dec & Mar & May & Sep & Dec & Mar & May & Sep & Jan & Mar & & & & & $\begin{array}{c}\text { effect } \\
\mathrm{p}\end{array}$ \\
\hline Pacific hake & 980 & 1459 & 5008 & 1152 & 2984 & 644 & 1749 & 2003 & 978 & 1237 & 271 & 2115 & 1715 & 1266 & 0.74 & 0.79 & 0.64 \\
\hline Pacific herring & 969 & 486 & 1149 & 583 & 459 & 271 & 1978 & 3557 & 505 & 1331 & 996 & 1828 & 1176 & 927 & 0.79 & 0.29 & 0.50 \\
\hline Walleye pollock & 12148 & 13073 & 5403 & 6010 & 13752 & 19603 & 7367 & 8816 & 6009 & 6929 & 5677 & 3895 & 9057 & 4636 & 0.51 & 0.03 & 0.02 \\
\hline Juvenile & 10027 & 11042 & 1064 & 4735 & 12635 & 18891 & 5050 & 6800 & 5732 & 6138 & 2096 & 1178 & & & & & \\
\hline Adult & 2121 & 2031 & 4339 & 1276 & 1117 & 713 & 2317 & 2016 & 277 & 791 & 3581 & 2716 & & & & & \\
\hline
\end{tabular}


Table 4. Longline survey estimates of relative abundance (catch in weight and number per 1000 hooks) during surveys of Frederick Sound, SE Alaska, by yr and mo. The other species category cumulatively accounts for less than $5 \%$ of the total catch by weight. P-values are based on a 2-factor ANOVA with no replication of relative abundance in weight

\begin{tabular}{|c|c|c|c|c|c|c|c|}
\hline \multirow[b]{2}{*}{ Species } & \multicolumn{3}{|c|}{ Catch $(\mathrm{kg})$ per 1000 hooks } & \multicolumn{3}{|c|}{ Catch (no.) per 1000 hooks } & \multirow[t]{2}{*}{$\mathrm{p}$} \\
\hline & Sep 2003 & Feb 2004 & May 2004 & Sep 2003 & Feb 2004 & May 2004 & \\
\hline Pacific halibut & 387 & 704 & 480 & 44 & 72 & 66 & 0.264 \\
\hline Sablefish & 228 & 102 & 30 & 72 & 41 & 12 & $<0.001$ \\
\hline Pacific cod & 92 & 219 & 220 & 36 & 88 & 92 & 0.001 \\
\hline Arrowtooth flounder & 73 & 16 & 28 & 27 & 7 & 15 & 0.012 \\
\hline Sandpaper skate & 25 & 31 & 23 & 6 & 9 & 6 & 0.570 \\
\hline Other & 34 & 85 & 28 & 15 & 35 & 15 & 0.002 \\
\hline Total & 839 & 1157 & 809 & 200 & 252 & 206 & 0.227 \\
\hline
\end{tabular}

galeatus, Pacific cod and dusky rockfish Sebastes ciliatus. More fish were captured by jigging in summer (266 fish representing 14 species) than in winter (97 fish representing 13 species). Fish captured by seining mostly were juveniles and were smaller (median size of pollock, Pacific herring, salmon, Pacific sand lance and Pacific cod was $\leq 80 \mathrm{~mm}$ ) than those captured by jigging (median size of sculpin, flatfish, Pacific cod, rockfish and greenling was $\geq 249 \mathrm{~mm}$ ). Species commonly observed with the ROV were juvenile gadids, Pacific sand lance, dusky rockfish and snake pricklebacks Lumpenus sagitta. Mean depth of observation and length of fish observed with the ROV were $43 \mathrm{~m}$ and $290 \mathrm{~mm}$ FL, respectively.

\section{Seasonal abundance and diet in relation to prey availability}

The pelagic species, pollock, herring and hake, were eaten frequently by Steller sea lions. Salmon and certain demersal prey, such as arrowtooth flounder, skates and Pacific cod, were also important in terms of biomass and energetic contribution to the diet, mainly due to their larger sizes. All of the targeted demersal prey were moderately sized and were typically found in shallow to intermediate depths. Small $(<8 \mathrm{~cm})$ nearshore species appear to have been ignored.

\section{Pelagic habitat}

Pollock, herring and hake generally were selected in Steller sea lion diet in proportion to their abundance in the environment. The overall odds ratio was close to zero, suggesting no general selection or avoidance of pollock, herring or hake for all seasons combined (Table 5). Pollock occurrence in the diet remained high throughout the yr (>90\%) (Fig. 2). Pollock was positively selected (odds ratio $>0.5$ ) in 4 periods (December 2001 and 2002, March 2003 and 2004) that were characterized by reduced relative abundance of pollock ( $<70 \%$ of total pelagic prey abundance) and preferential consumption of abundant yr classes (see below). An odds ratio analysis comparing juvenile and adult pollock found that selection for adult pollock in 2001 shifted to selection for juvenile pollock by 2004 . In addition, throughout the present study, adults were positively selected only in May and September.

The size of pollock eaten by Steller sea lions varied across collection periods, with YOY, juveniles and adults all consumed (mean $\pm \mathrm{SD}=25 \pm 9 \mathrm{~cm}$, range $=7$ to $76 \mathrm{~cm}, \mathrm{n}=5821$; ANOVA, $F_{14}=33.3$, $\mathrm{p}<0.001$ ). Adult pollock occurred most frequently during the 1st survey yr, after which younger fish dominated, especially juveniles 20 to $34 \mathrm{~cm}$ in length (Fig. 2). YOY pollock that were 4 to $6 \mathrm{~cm}$ long dominated nearshore beach seine catches $(>75 \%)$, but these small pollock

Table 5. Merluccius productus, Clupea pallasi and Theragra chalcogramma. $\log _{10}$ odds ratio values comparing 3 key pelagic species in Frederick Sound, SE Alaska, by yr and mo (first 3 rows labeled Pacific hake, Pacific herring and walleye pollock). Ratios were separately computed to compare juvenile and adult walleye pollock (fourth row labeled juvenile pollock). Positive values indicate apparent selection and negative values avoidance. Values exceeding 0.5 are in bold

\begin{tabular}{|c|c|c|c|c|c|c|c|c|c|c|c|c|}
\hline Species & & 2001 & & & 2002 & & & 2003 & & 2004 & & Overall \\
\hline & May & Sep & Dec & May & Sep & Dec & Mar & May & Sep & Jan & Mar & \\
\hline Pacific hake & 0.2 & 0.4 & -0.4 & -0.2 & 0.2 & -0.2 & -0.3 & -0.4 & -0.4 & 0.8 & -0.4 & -0.1 \\
\hline Pacific herring & 0.0 & -0.2 & -1.0 & 0.9 & 0.6 & -0.7 & -0.7 & 0.2 & 0.1 & -0.1 & -0.5 & -0.1 \\
\hline Walleye pollock & -0.1 & -0.3 & 0.5 & -0.3 & -0.4 & 0.5 & 0.6 & 0.1 & 0.1 & -0.3 & 0.6 & 0.1 \\
\hline Juvenile pollock & -1.1 & -0.6 & 0.2 & -1.1 & -1.0 & 0.3 & 0.1 & -0.7 & -0.3 & 0.7 & 1.0 & -0.2 \\
\hline
\end{tabular}


were never found in scat. Instead, sea lions began targeting small pollock 4 to 5 mo later during winter (December 2001, January 2004) when these small pollock had grown to $\sim 10-12 \mathrm{~cm}$, moved offshore and were detectable by acoustic surveys. Steller sea lions targeted abundant pollock yr classes, most obviously tracking the abundant $2001 \mathrm{yr}$ class through multiple years (December 2001, December 2002, March 2003). Across the 3 yr study period, 3 other yr classes of pollock (2000, 2002 and 2003) were targeted (Fig. 3).

In contrast to pollock, the herring sizes consumed by Steller sea lions were very consistent (mean $\pm \mathrm{SD}=$ $18 \pm 3 \mathrm{~cm}$, range $=5$ to $34 \mathrm{~cm}, \mathrm{n}=1277$ ) (Fig. 4). Despite significant statistical differences between collections (ANOVA, $F_{14}=9.8, \mathrm{p}<0.001$ ), the mean size of herring found in scats varied by only $3 \mathrm{~cm}$ (from 16 to $19 \mathrm{~cm}$ ), with fish 14 to $22 \mathrm{~cm}$ mostly selected. The nearshore beach seine surveys in July 2003 were dominated (>83\%) by 4 to $6 \mathrm{~cm}$ herring, but again these small YOY fish were completely ignored by Steller sea lions.

Hake were the largest frequently consumed pelagic species taken by Steller sea lions (mean $\pm \mathrm{SD}=37 \pm$ $7 \mathrm{~cm}$, range $=9$ to $63 \mathrm{~cm}, \mathrm{n}=532$ ) and, like pollock, the size of hake in the diet differed between collections (ANOVA, $F_{14}=8.8, \mathrm{p}<0.001$ ) (Fig. 4). No hake below $36 \mathrm{~cm}$ were found in trawls even though hake less than $20 \mathrm{~cm}$ were found in the diet. Overall, hake found in the diet were mainly confined to the smallest fish found in trawls.

A wide size range of salmon was eaten (mean $\pm \mathrm{SD}=$ $31 \pm 12 \mathrm{~cm}$, range $=12$ to $63 \mathrm{~cm}, \mathrm{n}=236$ ) (Fig. 4). DNA analysis identified September 2001 samples primarily as pink salmon and secondarily as coho salmon, and December 2001 samples primarily as chinook salmon and secondarily as pink salmon (Tollit et al. 2008). Cephalopods in the diet ranged widely in size (mean $=$ $141 \pm 334 \mathrm{~g}$, range $=1$ to $4853 \mathrm{~g}, \mathrm{n}=299$ ) and encom- passed both small squid and larger octopus. The smallest fish eaten by Steller sea lions were myctophids (mean $=8 \pm 2 \mathrm{~cm}$, range $=3$ to $12 \mathrm{~cm}, \mathrm{n}=88$ ) and northern smoothtongue (mean $=8 \pm 1 \mathrm{~cm}$, range $=7$ to $10 \mathrm{~cm}, \mathrm{n}=29$ ), which were similar to sizes in midwater trawl catches.

Energy density at $<30 \mathrm{~m}$ water depth diminished during December and March, suggesting that pelagic species vacated shallow depths during winter (Fig. 5). Likewise, nearshore species abundance was significantly less during December compared to July. However, our sampling focused primarily on daylight hours. Based on occasional qualitative (checking vessel depth sounder while anchored at night) and limited quantitative nighttime sampling, pelagic species moved shallower during nighttime (Fig. 6).

\section{Demersal and nearshore habitats}

Arrowtooth flounder, Pacific cod and skates, but not halibut or sablefish, were important dietary items, even though all 5 species were abundant demersal species (Table 4). Log-odds-ratio analysis was possible for September 2003 and for the combined period February and May 2004. In both periods, arrowtooth flounder was strongly selected $(\mathrm{O}=+0.7$ and +1.4 , respectively), skates were selected in September $(\mathrm{O}=+1.4)$ but not February/May $(\mathrm{O}=+0.3)$ and cod dietary importance was proportional to abundance in the environment in September $(\mathrm{O}=0)$ and February/May $(\mathrm{O}=$ +0.3 ). Halibut and sablefish were avoided. Pacific halibut and sablefish were common longline-caught species, but just 2 large $(\sim 90 \mathrm{~cm})$ halibut and no sablefish were found in scats. Steller sea lions selected small arrowtooth flounder. Most (81\%) arrowtooth flounder $($ mean $\pm \mathrm{SD}=43 \pm 9 \mathrm{~cm}$, range $=15$ to $73 \mathrm{~cm}, \mathrm{n}=370)$

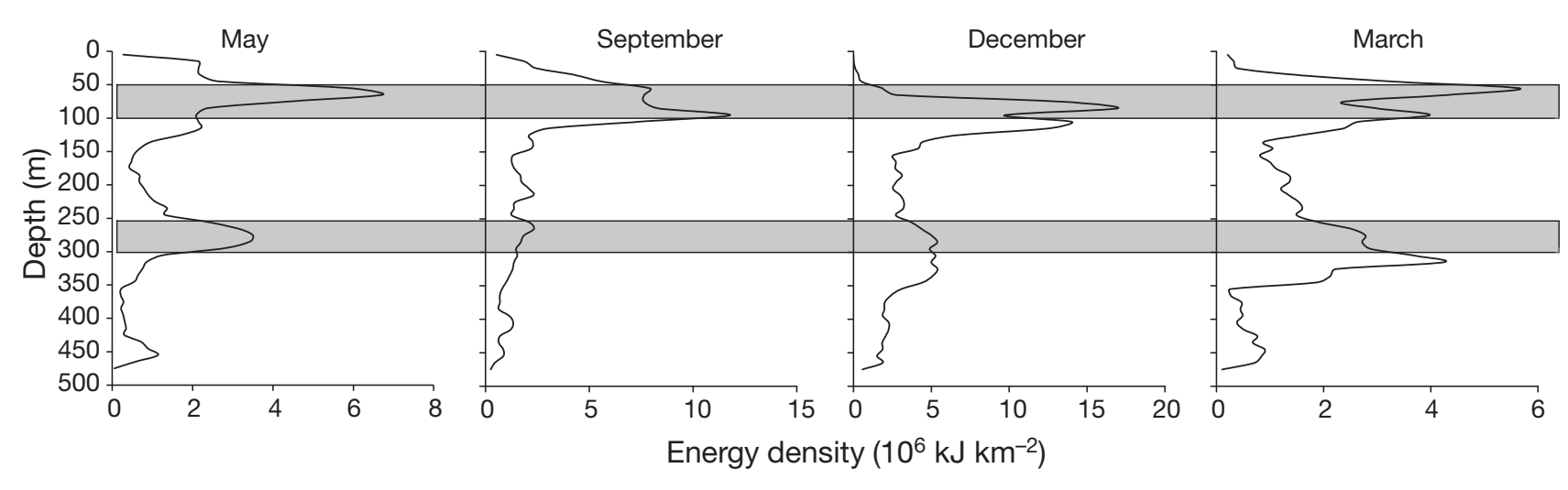

Fig. 5. Theragra chalcogramma, Merluccius productus and Clupea pallasi. Energy density $\left(10^{6} \mathrm{~kJ} \mathrm{~km}^{-2}\right)$ of pelagic species (walleye pollock, Pacific hake and Pacific herring) measured by acoustic surveys in Frederick Sound, SE Alaska, during daylight by depth interval (m) and season (May, September, December, March). Light gray shades highlight the bimodal depth distributions that run through all panels 


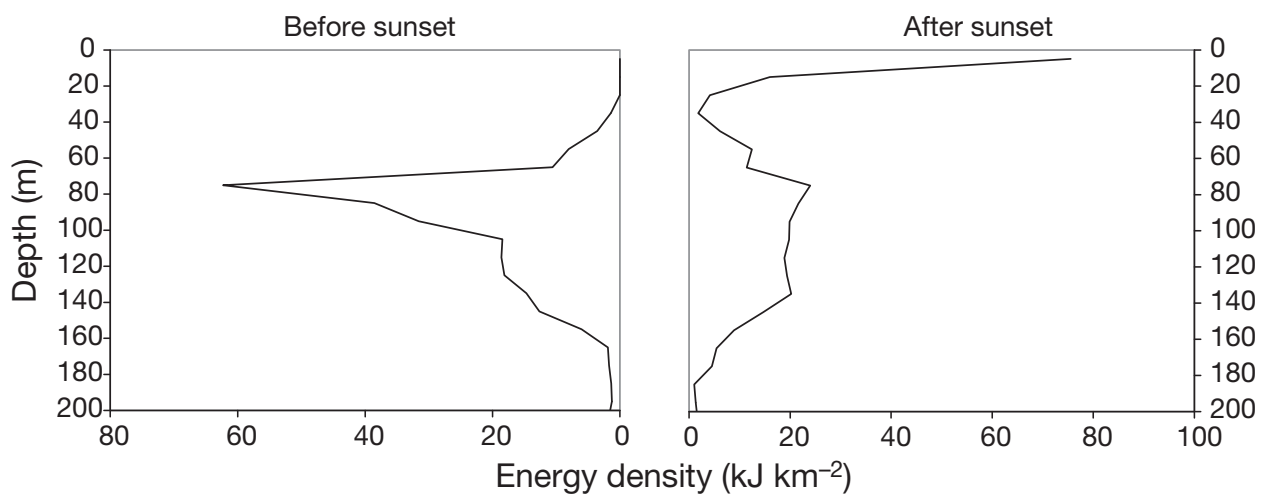

Fig. 6. Theragra chalcogramma, Merluccius productus and Clupea pallasi. Energy density $\left(10^{6} \mathrm{~kJ} \mathrm{~km}^{-2}\right)$ of pelagic species (walleye pollock, Pacific hake and Pacific herring) measured by acoustic surveys in Frederick Sound, SE Alaska, by depth interval (m) from 27 to 28 May 2001 during $4 \mathrm{~h}(18: 00-21: 00 \mathrm{~h})$ before and $6 \mathrm{~h}(22: 00-03: 00 \mathrm{~h})$ after sunset $(21: 44 \mathrm{~h})$. Plots are shown as mirror images of each other (using sunset as the line that separates each half)

in scats were 35 to $60 \mathrm{~cm}$ in length, whereas most longline sizes were 50 to $75 \mathrm{~cm}$ (Fig. 4). Steller sea lions also selected small skates. Most (73\%) skates (mean $=48 \pm$ $19 \mathrm{~cm}$, range $=23$ to $111 \mathrm{~cm}, \mathrm{n}=235$ ) were 35 to $50 \mathrm{~cm}$ in length, whereas most longline sizes were 55 to $75 \mathrm{~cm}$. Pacific cod were shallower (average depth of $192 \mathrm{~m}$ based on longline surveys) than arrowtooth flounder (254 m), halibut (248 m) and sandpaper skate $(260 \mathrm{~m})$, which in turn were shallower than sablefish (305 m). Juvenile cod, but no other longline-caught species, were common in nearshore surveys (beach seines $<5 \mathrm{~m}$, jigging 5 to $115 \mathrm{~m}$, ROV 1 to $85 \mathrm{~m}$ ) (Thedinga et al. 2006).

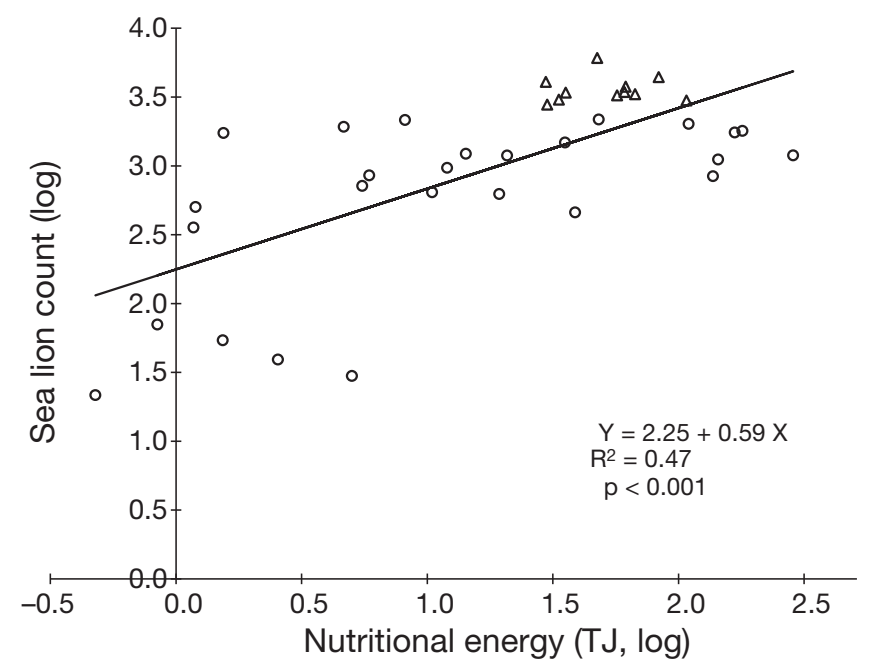

Fig. 7. Theragra chalcogramma, Merluccius productus and Clupea pallasi. Relationship between nutritional energy (TJ, log) of pelagic species (walleye pollock, Pacific hake and Pacific herring) and number (log) of Steller sea lions at 2 areas in SE Alaska: Frederick Sound $(\Delta)$ and Lynn Canal (O)
Rockfish and juvenile Pacific cod, but not small $(<10 \mathrm{~cm})$ pollock, herring or Pacific sand lance, were important dietary items, even though all 5 species were abundant nearshore species (Thedinga et al. 2006). Only larger sand lance and Cottidae were present in scats, even though summer beach seine survey catches were dominated by small pollock (4 to $6 \mathrm{~cm}$ ) and herring (4 to $6 \mathrm{~cm}$ ), with smaller catches of sand lance, chum salmon, Cottidae and small Pacific cod $(<10 \mathrm{~cm})$ (Fig. 4). Pacific cod present in scats encompassed jig and longline survey sizes and were larger than beach seine survey sizes. Rockfish present in scats encompassed jig survey sizes as well as larger fish. Rock sole present in scats were similar to jig survey sizes.

\section{Steller sea lion numerical response}

More sea lions were present when more prey was available, demonstrating a numerical response between Steller sea lion abundance and available nutritional energy. There was a significant relationship between $\log$ (number of sea lions) and $\log$ (nutritional energy of pelagic prey; in TJ) $\left(\mathrm{R}^{2}=0.47, F_{1,35}=30.9\right.$, $\mathrm{p}<0.001$ ) (Fig. 7).

\section{DISCUSSION}

\section{Diet choice and prey availability}

Steller sea lions shifted diet composition in response to changes in prey availability of pollock, hake, herring and salmon. Steller sea lions switched from adult pollock at the start of the study period in 2001 and earlier 
(1994 to 1999) (Tollit et al. 2004) to juvenile pollock from 2002 to 2004 . They targeted 20 to $34 \mathrm{~cm}$ fish and tracked strong yr classes, most obviously the strong $2001 \mathrm{yr}$ class through 3 yr (2001 to 2003, Figs. 2 \& 3). Hake consumption expanded from sporadic low-level occurrences in summer and fall only (Trites et al. 2007, Tollit et al. 2008) to year-round (present study) as hake expanded northward during warm El Niño periods in the late 1990s (Ressler et al. 2007) and apparently remained in Frederick Sound (present study). Herring dietary occurrence peaked each yr in May-July (Fig. 2), coincident with herring spawning. Salmon dietary occurrence (September, Fig. 2) and Steller sea lion counts at terrestrial sites ( 2000 sea lions, August or September, Table 1) peaked each yr coincident with the runtiming of spawning pink salmon.

Steller sea lions preyed upon the most abundant pelagic prey but ignored some species in demersal and nearshore habitats. In Frederick Sound, pollock were the most abundant pelagic species and were a dietary staple year-round, occurring in $95 \%$ of scats and contributing $1 / 3$ of the diet in terms of energy (Table 2). Hake and herring were on average 5- and 8-fold less abundant than pollock (Table 3 ) and occurred less frequently in sea lion diets, resulting in biomass contributions that in both cases were $\sim 7$-fold less than that of pollock (Table 2). Two demersal species, halibut and sablefish, were ignored, possibly because both are strong swimmers. Additionally, halibut were large (average $8.5 \mathrm{~kg}$ ) and sablefish were deep (average $305 \mathrm{~m}$ ). Steller sea lions tended to select intermediate-sized fish and avoid small $(<10 \mathrm{~cm})$ and large $(>60 \mathrm{~cm})$ fish. Halibut dominated the demersal species abundance, whereas the smaller arrowtooth flounder and skate (average 2.3 and $3.8 \mathrm{~kg}$, respectively) were less common. However, the 2 smaller demersal species were energetically important in sea lion diet (arrowtooth flounder EC $=17 \%$, skate EC = $12 \%)$, whereas halibut was strongly avoided.

Small fish, typically in nearshore areas, were also ignored despite periodic abundance. Very few small $(<8 \mathrm{~cm})$ fish were found in scats, even when YOY pollock were abundant in summer 2001 (mean catch per beach seine haul $=5878)$ (Thedinga et al. 2006). Instead, YOY pollock were consumed by sea lions in winter when the fish were larger (10 to $12 \mathrm{~cm}$ ) and in deeper water. This pattern is not due to Steller sea lions avoiding nearshore areas, as individually tracked juvenile Steller sea lions in SE Alaska preferentially traveled nearshore and minimized the length of open water crossings (B. Wilson \& M. A. Lea pers. comm.). Although accessible, the capture cost for many small fish is likely higher than the equivalent biomass of a few large fish.

Steller sea lions sometimes selected less nutritious fish if located nearby their haulouts. Port Houghton forms a main bay with a distinct arm at the back of the main bay (Fig. 1). An occasionally used haulout, Walter Island, is centrally located in the main bay about $9 \mathrm{~km}$ away from the arm and is the only known haulout in Port Houghton. In December 2002, the main bay contained $1200 \mathrm{t}$ of pollock, while the arm contained $600 \mathrm{t}$ of herring and $80 \mathrm{t}$ of pollock. During daylight, pollock in the main bay ( 80 to $130 \mathrm{~m}$ ) were shallower than herring in the arm (120 to $160 \mathrm{~m}$ ) and both species were closer to the surface at night. All scats from Walter Island contained pollock and one-quarter also contained herring. The common occurrence of pollock in scats at Walter Island indicates that: (1) even though herring energy density is about $80 \%$ greater than pollock (Vollenweider et al. 2006), pollock are worth preying upon; and (2) even when herring are preyed upon, pollock are not avoided. The frequent occurrence of herring in these scats indicates that sea lions periodically chose to travel farther to obtain energy-rich forage fish. Availability also was important for prey selection by harbor seals, which adopted a pelagic foraging strategy when clupeid prey was abundant and switched to a demersal foraging strategy when clupeid abundance was low (Tollit et al. 1997a). Likewise, Steller sea lions in Prince William Sound, Alaska, preyed upon herring when they were less abundant but more accessible than pollock (Thomas \& Thorne 2001).

Prey predictability also affects prey selection by Steller sea lions. Herring in Frederick Sound appear less predictable compared to other areas such as Lynn Canal, where herring is far more frequent in sea lion diets (90\% FO in Lynn Canal vs. 33\% in Frederick Sound). Herring appeared irregularly in satellite bays of Frederick Sound and were abundant in as few as one and as many as 4 bays in a sampling period. In contrast, large, predictable herring schools were present November through February in Lynn Canal (Womble \& Sigler 2006, Sigler \& Csepp 2007), and their persistence was an important characteristic in determining whether foraging Steller sea lions utilized them (Gende \& Sigler 2006).

Juvenile Steller sea lion dive patterns followed seasonal shifts in prey depth distribution. During the day, prey were less abundant at depths $<50 \mathrm{~m}$ during winter than summer for both pelagic (Fig. 5) and nearshore (Thedinga et al. 2006) species. Individuals reached greater depths during December (maximum daily depth $=99 \mathrm{~m}$ ) than May-July $(85 \mathrm{~m})$. Juvenile Steller sea lions are capable of diving deeper than these depths; their deepest dives reached $200 \mathrm{~m}$ by $1 \mathrm{yr}$ of age and exceeded $400 \mathrm{~m}$ by $3 \mathrm{yr}$ of age (Pitcher et al. 2005).

Diet diversity in Frederick Sound generally was similar in summer and higher in winter than that found in 
several other regions of Alaska. In Frederick Sound, species diversity in Steller sea lion diets peaked in autumn and early spring, reflecting increased contributions from arrowtooth flounder, salmon, hake and Pacific cod. The values were similar to diversity indices calculated using scats collected at other haulouts in SE Alaska (September-May, Frederick Sound = 3.6 vs. other haulouts in southeast Alaska $=4.1$ ), but were lower than the diverse diets at coastal rookeries in southeast Alaska (June-July, Frederick Sound = 2.9 vs. southeast Alaska rookeries = 5.3) (Trites et al. 2007). Prey family diversity in Steller sea lion diets during summer in Frederick Sound (May-September, 2.3) was similar to that in the eastern Aleutians (2.0) and western Gulf of Alaska (2.1) (Sinclair \& Zeppelin 2002) and higher than that in the central Gulf of Alaska (1.7) and central and western Aleutians (1.5) (Sinclair \& Zeppelin 2002). In winter, prey family diversity in Frederick Sound (October-April, 2.6) was higher than that in the eastern Aleutians and western and central Gulf of Alaska (1.8 to 2.1) and in the central and western Aleutians (1.9) (Sinclair \& Zeppelin 2002).

Steller sea lions exhibit a flexible foraging strategy. Their diet composition shifts from a simpler diet dominated by Atka mackerel in the western and central Aleutian Islands to more complex diets with multiple important species (FO > 35\%) in the eastern Aleutian Islands, Gulf of Alaska and SE Alaska (Sinclair \& Zeppelin 2002, Trites et al. 2007) (Fig. 2). Salmon and pollock were important in the eastern Aleutian Islands and western Gulf of Alaska, while salmon, pollock, forage fish and arrowtooth flounder were dominant in the central Gulf of Alaska, and salmon, pollock and forage fish occurred most frequently in SE Alaska (Table 2) (Sinclair \& Zeppelin 2002, Trites et al. 2007, McKenzie \& Wynne 2008).

A flexible foraging strategy confers several advantages. Steller sea lions may take advantage of seasonal prey aggregations that presumably are easier to capture due to high prey density and choose prey with higher energy content (Sinclair \& Zeppelin 2002). This strategy buffers Steller sea lions against seasonally varying energetic requirements which vary across seasons due to the demands of pregnancy, lactation and fasting during the breeding period (Winship et al. 2002). For example, energy intake by captive California sea lions Zalophus californianus during lactation and immediately post-lactation (August-February) was nearly $4 \times$ maintenance levels (Williams et al. 2007). A flexible foraging strategy also buffers Steller sea lions against variation in ocean productivity which varies on decadal (Francis et al. 1998) and longer time scales (Baumgartner et al. 1992) and can affect prey composition and abundance (Anderson \& Piatt 1999). California sea lions exhibit annual diet changes correspond- ing to large-scale ocean climate shifts (Weise and Harvey 2008), similar to the entrance of hake into the diet of Steller sea lions in Frederick Sound. Several life history strategies including longevity, parental investment in offspring, fasting capability (Iverson et al. 2007) and reproductive failure during late gestation (Pitcher et al. 1998) buffer Steller sea lions against variation in ocean productivity. These traits likely help individual Steller sea lions survive periods of reduced prey abundance or quality and, at the population level, dampen swings in Steller sea lion abundance.

\section{Shifts among seasonally available prey}

Steller sea lions move between areas as prey becomes available seasonally. Steller sea lions were present in Frederick Sound year-round, whereas they were found in Lynn Canal primarily from November to March (Womble \& Sigler 2006) and in Berners Bay only during April and May (Gende et al. 2001, Marston et al. 2002, Sigler et al. 2004). These seasonal changes in location appear related to seasonal differences in prey availability. In Frederick Sound, prey was abundant (e.g. average pelagic fish biomass was $5 \times$ higher than the monthly consumption estimate) and pollock and hake were common (Table 3) year-round. In contrast, herring were concentrated in Lynn Canal only during November to April (Sigler \& Csepp 2007) and eulachon were concentrated in Berners Bay only during April and May (Marston et al. 2002, Sigler et al. 2004). Diet studies imply that the western population of Steller sea lions also follows strong seasonal patterns in consumption of most species of prey (Sinclair \& Zeppelin 2002, Sinclair et al. 2005).

Steller sea lions move from place to place as part of an annual foraging strategy in SE Alaska to forage on herring aggregations in winter, fish spawning aggregations in spring, salmon in summer and fall (depending on species) and pollock and Pacific hake throughout the yr. First described in an analysis of aerial survey data on 28 haulouts in southeast Alaska (Womble et al. 2009), this strategy also is supported by aerial survey, prey and diet data from this study (salmon available in fall, pollock and Pacific hake yearround) and the companion studies in Lynn Canal (herring aggregations in winter) (Womble \& Sigler 2006) and Berners Bay (fish spawning aggregations in spring) (Sigler et al. 2004). Moving between areas of seasonal concentrations of high quality prey (multiple central place foraging) also confers the advantage of reducing overall travel costs and providing access to a larger foraging area (Chapman et al. 1989) if prey quantity in one area is insufficient due to depletion or seasonality. 


\section{Numerical response}

The number of Steller sea lions present depended on the amount of prey available (Fig. 7). This relationship reasonably estimates the nutritional energy necessary to attract and sustain Steller sea lions because the eastern population has grown since the 1970s (Pitcher et al. 2007), which implies nutritional requirements were met. The estimated numerical response implies that $0.3 \mathrm{TJ}$ are sufficient nutritional energy for 100 sea lions, $5 \mathrm{TJ}$ for 500 sea lions and $20 \mathrm{TJ}$ for 1000 sea lions. Translating to biomass and applying the range of energy densities measured in the present study ( 3 to $10 \mathrm{~kJ} \mathrm{~g}^{-1}$ ), the relationship implies that 500 to $1700 \mathrm{t}$ of prey are needed near a terrestrial location where 500 sea lions haul out, depending on the species composition of the prey. 'Near' is loosely defined as the radius of our study area, which was $20 \mathrm{~km}$. These prey amounts far exceed energetic requirements of individual Steller sea lions. For example, assuming a daily ration of $79464 \mathrm{~kJ}$ per sea lion (Sigler et al. 2004), 5 TJ for 500 sea lions provides about 63000 daily rations. Steller sea lions may require rich foraging locations to thrive, or Frederick Sound may be the most attractive among competing rich foraging locations. The numerical response is nonlinear; more energy per sea lion is necessary to attract many sea lions than few sea lions $(0.003,0.011$ and $0.2 \mathrm{TJ}$ per individual for 100, 500 and 1000 sea lions, respectively), and may indicate that foraging costs are density-dependent. Steller sea lion foraging may disrupt fish schools, thus reducing captures in successive foraging bouts. Steller sea lions foraged alone or in small groups ( $\leq 20$ individuals) in Frederick Sound, though they sometimes cooperatively foraged in large groups of 10 s to 100 s of individuals for eulachon in Berners Bay (Gende et al. 2001, Sigler et al. 2004).

\section{Nutrition and diet diversity}

A diet dominated by less nutritious prey (e.g. gadids such as pollock) was proposed to have caused nutritional stress and contributed to the decline of the western stock of Steller sea lions (Alverson 1992, Trites \& Donnelly 2003). In contrast, eastern stock abundance has increased by about $3 \% \mathrm{yr}^{-1}$ since the $1970 \mathrm{~s}$ (Pitcher et al. 2007), yet pollock occurred at higher frequency in Steller sea lion scats in inside waters of SE Alaska, including Frederick Sound, Stephens Passage and Lynn Canal (Table 2) (Womble \& Sigler 2006, Trites et al. 2007), than in the coastal rookeries of SE Alaska ( $60 \%$, Trites et al. 2007), the central ( 40 to $60 \%)$ and western $(\sim 80 \%)$ Gulf of Alaska and eastern $(\sim 60 \%)$, central and western $(\sim 10 \%)$ Aleutians (Sin- clair \& Zeppelin 2002, McKenzie \& Wynne 2008). Pollock comprised $34 \%$ of the energetic contribution and $39 \%$ of the biomass contribution in Frederick Sound, approaching the $45 \%$ biomass contribution of pollock to Steller sea lions in the Kodiak area after sea lion abundance began to decline there (Atkinson et al. 2008a). Together, gadid species contributed $50 \%$ of the biomass and $44 \%$ of the energetic contribution in Frederick Sound. Pollock also may be selected when more nutritious herring are nearby (e.g. Port Houghton) and can commonly occur with herring $(\sim 90 \%)$ in sea lion diets, even when herring are more abundant than pollock in an area (Womble \& Sigler 2006). Obtaining a healthy diet that is dominated by less nutritious prey likely depends on including a proportion of nutritious prey, as sea lions sometimes traveled farther to obtain herring even when pollock were plentiful nearby (e.g. Port Houghton). These observations imply that a diet with substantial year-round contributions from less nutritious but abundant prey, such as pollock, can form part of a healthy diet as long as more nutritious prey such as herring, salmon or eulachon also are consumed, as in SE Alaska.

The diverse diet (salmon, pollock and forage fish), abundant quantity and presence of some high quality prey (salmon, herring and eulachon) likely sustains the increasing population in SE Alaska. Nearly $1 / 3$ of all scats collected contained only pollock, but the remainder contained other prey such as herring and arrowtooth flounder, implying sea lions have a flexible foraging strategy, even at the trip level. Seasonal switches to salmon, hake and skate also support the flexible foraging strategy with little direct selection evident beyond accessible prey and fairly broad prey size preferences. Pollock's importance may lie in its steady availability that provides a food source that is always available in case seasonal aggregations show up weak or not at all.

Our study supports the conclusion that a flexible foraging strategy and diverse diet help marine predators compensate for less nutritious prey. Animal species with limited ability to carry food loads back to their young and energetically expensive foraging behavior likely are particularly sensitive to food quality (Österblom et al. 2008). Less nutritious prey and a focus on 1 or 2 prey species led to reproductive failure in the common guillemot Uria aalge (Wanless et al. 2005, Österblom et al. 2006). Black-legged kittiwakes Rissa tridactyla compensated for food shortages during nesting by increased parental investment, while thickbilled murres Uria lomvia did not and chick growth decreased (Kitaysky et al. 2000). In contrast, seal and sea lion species chose the most abundant prey within a suite of preferred species (Thompson et al. 1991, Bowen \& Harrison 1994, Tollit et al. 1997a) and switched prey when prey abundance changed (Bailey 
\& Ainley 1982, Sinclair et al. 1994, Tollit et al. 1997a, Weise and Harvey 2008). We found that Steller sea lions switch prey in response to changes in prey abundance, move to take advantage of seasonally available prey and can rely on less nutritious species as long as more nutritious prey are also consumed.

Acknowledgements. We appreciate reviews by L. Fritz, M. A. Lea and M. Willson. T. Gelatt led the sea lion satellite telemetry effort. Financial support was provided to A.W.T. and D.J.T. by NOAA and the North Pacific Marine Science Foundation through the North Pacific Universities Marine Mammal Research Consortium.

\section{LITERATURE CITED}

Alverson DL (1992) A review of commercial fisheries and the Steller sea lion (Eumetopias jubatus): the conflict arena. Rev Aquat Sci 6:203-256

Anderson PJ, Piatt JF (1999) Community reorganization in the Gulf of Alaska following ocean climate regime shift. Mar Ecol Prog Ser 189:117-123

Atkinson S, Calkins D, Burkanov V, Castellini M, Hennen D, Inglis $S$ (2008a) Impact of changing diet regimes on Steller sea lion body condition. Mar Mamm Sci 24:276-289

Atkinson S, DeMaster DP, Calkins DG (2008b) Anthropogenic causes of the western Steller sea lion Eumetopias jubatus population decline and their threat to recovery. Mammal Rev 38:1-18

Bailey KM, Ainley DG (1982) The dynamics of California sea lion predation on Pacific hake. Fish Res 1:163-176

Baumgartner TR, Soutar A, Ferreirabartrina V (1992) Reconstruction of the history of Pacific sardine and northern anchovy populations over the past 2 millennia from sediments of the Santa Barbara Basin, California. Calif Coop Ocean Fish Invest Rep 33:24-40

Beck CA, Bowen WD, McMillan JI, Iverson SJ (2003) Sex differences in the diving behaviour of a size-dimorphic capital breeder: the grey seal. Anim Behav 66:777-789

Bigg MA, Olesiuk PF (1990) An enclosed elutriator for processing marine mammal scats. Mar Mamm Sci 6:350-355

Bowen WD, Harrison GD (1994) Offshore diet of grey seals Halichoerus grypus near Sable Island, Canada. Mar Ecol Prog Ser 112:1-11

Browne P, Laake JL, DeLong RL (2002) Improving pinniped diet analyses through identification of multiple skeletal structures in fecal samples. Fish Bull 100:423-433

Chapman CA, Chapman LJ, McLaughlin RL (1989) Multiple central place foraging by spider monkeys: travel consequences of using many sleeping sites. Oecologia 79: 506-511

> Coyle K, Hunt GL Jr, Decker MB, Weingartner TJ (1992) Murre foraging, epibenthic sound scattering and tidal advection over a shoal near St. George Island, Bering Sea. Mar Ecol Prog Ser 83:1-14

Fleiss J (1981) Statistical methods for rates and proportions. John Wiley, London

Ford JKB, Ellis GM (2006) Selective foraging by fish-eating killer whales Orcinus orca in British Columbia. Mar Ecol Prog Ser 316:185-199

> Francis RC, Hare SR, Hollowed AB, Wooster WS (1998) Effects of interdecadal climate variability on the oceanic ecosystems of the NE Pacific. Fish Oceanogr 7:1-21

Gende SM, Sigler MF (2006) Persistence of forage fish 'hot spots' and its association with foraging Steller sea lions (Eumetopias jubatus) southeast Alaska. Deep-Sea Res I 53: 432-441

Gende SM, Womble JN, Willson MF, Marston BH (2001) Cooperative foraging by Steller sea lions, Eumetopias jubatus. Can Field Nat 115:355-356

> Hammond PS, Rothery P (1996) Application of computer sampling in the estimation of seal diet. J Appl Stat 23:525-533

$>$ Holmes EE, Fritz LW, York AE, Sweeney K (2007) Age-structured modeling reveals long-term declines in the natality of western Steller sea lions. Ecol Appl 17:2214-2232

Hunt GL Jr, Russel RR, Coyle KO, Weingartner T (1998) Comparative foraging ecology of planktivorous auklets in relation to ocean physics and prey availability. Mar Ecol Prog Ser 167:241-259

> Huse I, Korneliussen R (2000) Diel variation in acoustic density measurements of overwintering herring (Clupea harengus L.). ICES J Mar Sci 57:903-910

Hyslop EJ (1980) Stomach contents analysis: a review of methods and their application. J Fish Biol 17:411-429

Irons DB (1998) Foraging area fidelity of individual seabirds in relation to tidal cycles and flock feeding. Ecology 79: $647-655$

Iverson SJ, Springer AM, Bodkin J (2007) Marine mammals. In: Spies RB (ed) Long-term ecological change in the northern Gulf of Alaska. Elsevier, Oxford, p 114-135

Jeanniard du Dot T, Rosen DAS, Trites AW (2008) Steller sea lions show diet-dependent changes in body composition during nutritional stress and recover more easily from mass loss in winter than in summer. J Exp Mar Biol Ecol 367:1-10

- Kitaysky AS, Hunt GL Jr, Flint EN, Rubega MA, Decker MB (2000) Resource allocation in breeding seabirds: responses to fluctuations in their food supply. Mar Ecol Prog Ser 206:283-296

> Kumagai S, Rosen DAS, Trites AW (2006) Body mass and composition responses to short-term low energy intake are seasonally dependent in Steller sea lions (Eumetopias jubatus). J Comp Physiol B 176:589-598

Laake JL, Browne P, DeLong RL, Huber HR (2002) Pinniped diet composition: a comparison of estimation models. Fish Bull 100:434-447

Lance MM, Orr AJ, Riemer SD, Weise MJ, Laake JL (2001) Pinniped food habits and prey identification techniques protocol. AFSC Processed Rep 2001-04, Alaska Fish Sci Cent, NOAA Natl Mar Fish Serv, Seattle, WA

> Loughlin TR, Perlov AS, Vladimirov VA (1992) Range-wide survey and estimation of total number of Steller sea lions in 1989. Mar Mamm Sci 8:220-239

MacLennan DN, Simmonds EJ (1992) Fisheries acoustics. Chapman \& Hall, New York

Marcotte ML (2006) Steller watch: timing of weaning and seasonal patterns in numbers and activities of Steller sea lions at a year-round haulout site in Southeast Alaska. MS thesis, University of British Columbia, Vancouver, BC

Marston BH, Willson MF, Gende SM (2002) Predator aggregations during eulachon Thaleichthys pacificus spawning runs. Mar Ecol Prog Ser 231:229-236

McKenzie J, Wynne KM (2008) Spatial and temporal variation in the diet of Steller sea lions in the Kodiak Archipelago, 1999 to 2005. Mar Ecol Prog Ser 360:265-283

Merrick RL, Loughlin TR (1997) Foraging behavior of adult female and young-of-the-year Steller sea lions in Alaskan waters. Can J Zool 75:776-786

Merrick RL, Chumbley MK, Byrd GV (1997) Diet diversity of Steller sea lions (Eumetopias jubatus) and their population decline in Alaska: a potential relationship. Can J Fish 
Aquat Sci 54:1342-1348

Middlemas SJ, Barton TR, Armstrong JD, Thompson PM (2006) Functional and aggregative responses of harbour seals to changes in salmonid abundance. Proc R Soc Lond B Biol Sci 273:193-198

Olesiuk PF, Bigg MA, Ellis GM, Crockford SJ, Wigen RJ (1990) An assessment of the feeding habits of harbour seals (Phoca vitulina) in the Strait of Georgia British Columbia based on scat analysis. Can Tech Rep Fish Aquat Sci 1730

Ona E (2003) An expanded target-strength relationship for herring. ICES J Mar Sci 60:493-499

Österblom H, Casini M, Olsson O, Bignert A (2006) Fish, seabirds and trophic cascades in the Baltic Sea. Mar Ecol Prog Ser 323:233-238

Österblom H, Olsson O, Blenckner T, Furness RW (2008) Junk-food in marine ecosystems. Oikos 117:967-977

Ostfeld RS (1982) Foraging strategies and prey switching in the California sea otter. Oecologia 53:170-178

Pascual MA, Adkison MD (1994) The decline of the Steller sea lion in northeast Pacific: Demography, harvest or environment? Ecol Appl 4:393-403

> Pitcher KW, Calkins DG (1981) Reproductive biology of Steller sea lions in the Gulf of Alaska. J Mammal 62: 599-605

Pitcher KW, Calkins DG, Pendleton GW (1998) Reproductive performance of female Steller sea lions: an energeticsbased reproductive strategy? Can J Zool 76:2075-2083

Pitcher KW, Rehberg MJ, Pendleton GW, Raum-Suryan KL, Gelatt TS, Swain UG, Sigler MF (2005) Ontogeny of dive performance in pup and juvenile Steller sea lions in Alaska. Can J Zool 83:1214-1231

Pitcher KW, Olesiuk PF, Brown RF, Lowry MS and others (2007) Abundance and distribution of the eastern North Pacific Steller sea lion (Eumetopias jubatus) population. Fish Bull 105:102-115

> Raum-Suryan KL, Rehberg MJ, Pendleton GW, Pitcher KW, Gelatt TS (2004) Development of dispersal, movement patterns, and haulout use by pup and juvenile Steller sea lions (Eumetopias jubatus) in Alaska. Mar Mamm Sci 20: 823-850

Rehberg MJ, Burns JM (2008) Differences in diving and swimming behavior of pup and juvenile Steller sea lions (Eumetopias jubatus) in Alaska. Can J Zool 86:539-553

Ressler PH, Holmes JA, Fleischer GW, Thomas RE, Cooke KC (2007) Pacific hake, Merluccius productus, autecology: a timely review. Mar Fish Rev 69:1-24

> Rosen DAS, Trites AW (2004) Satiation and compensation for short-term changes in food quality and availability in young Steller sea lions (Eumetopias jubatus). Can J Zool 82:1061-1069

Rosen DAS, Trites AW (2005) Examining the potential for nutritional stress in young Steller sea lions: physiological effects of prey composition. J Comp Physiol B 175:265-273

Sigler MF, Csepp DJ (2007) Seasonal abundance of two important forage species in the North Pacific Ocean, Pacific herring and walleye pollock. Fish Res 83:319-331

Sigler MF, Womble JN, Vollenweider JJ (2004) Availability to Steller sea lions (Eumetopias jubatus) of a seasonal prey resource: a prespawning aggregation of eulachon (Thaleichthys pacificus). Can J Fish Aquat Sci 61:1475-1484

Similä T, Holst JC, Christensen I (1996) Occurrence and diet of killer whales in northern Norway: seasonal patterns relative to the distribution and abundance of Norwegian spring-spawning herring. Can J Fish Aquat Sci 53:769-779

> Sinclair EH, Zeppelin TK (2002) Seasonal and spatial differences in diet in the western stock of Steller sea lions
(Eumetopias jubatus). J Mammal 83:973-990

Sinclair E, Loughlin T, Pearcy W (1994) Prey selection by northern fur seals (Callorhinus ursinus) in the eastern Bering Sea. Fish Bull 92:144-156

> Sinclair EH, Moore SE, Friday NA, Zeppelin TK, Waite JM (2005) Do patterns of Steller sea lion (Eumetopias jubatus) diet, population trend and cetacean occurrence reflect oceanographic domains from the Alaska Peninsula to the central Aleutian Islands? Fish Oceanogr 14:223-242

Skov H, Durinck J, Andell P (2000) Associations between wintering avian predators and schooling fish in the Skagerrak-Kattegat suggest reliance on predictable aggregations of herring Clupea harengus. J Avian Biol 31:135-143

Thedinga JF, Johnson SW, Csepp DJ (2006) Nearshore fish assemblages in the vicinity of two Steller sea lion haulouts in southeastern Alaska. In: Trites AW, Atkinson SK, DeMaster DP, Fritz LW, Gelatt TS, Rea LD, Wynne KM (eds) Sea lions of the world. Alaska Sea Grant Program Rep AK-SG-06-01, University of Alaska, Fairbanks, AK

> Thomas GL, Thorne RE (2001) Night-time predation by Steller sea lions. Nature 411:1013

> Thompson PM, Pierce GJ, Hislop JRG, Miller D, Diack JSW (1991) Winter foraging by common seals (Phoca vitulina) in relation to food availability in the Inner Moray Firth, NE Scotland. J Anim Ecol 60:283-294

Tollit DJ, Greenstreet SPR, Thompson PM (1997a) Prey selection by harbour seals, Phoca vitulina, in relation to variations in prey abundance. Can J Zool 75:1508-1518

Tollit DJ, Steward MJ, Thompson PM, Pierce GJ, Santos MB, Hughes S (1997b) Species and size differences in the digestion of otoliths and beaks: implications for estimates of pinniped diet composition. Can J Fish Aquat Sci 54: 105-119

Tollit DJ, Wong M, Winship AJ, Rosen DAS, Trites AW (2003) Quantifying errors associated with using prey skeletal structures from fecal samples to determine the diet of Steller's sea lion (Eumetopias jubatus). Mar Mamm Sci 19: $724-744$

Tollit DJ, Heaslip SG, Zeppelin TK, Joy R, Call KA, Trites AW (2004) A method to improve size estimates of walleye pollock (Theragra chalcogramma) and Atka mackerel (Pleurogrammus monopterygius) consumed by pinnipeds: digestion correction factors applied to bones and otoliths recovered in scats. Fish Bull 102:498-508

- Tollit DJ, Heaslip SG, Barrick RL, Trites AW (2007) Impact of diet-index selection and the digestion of prey hard remains on determining the diet of the Steller sea lion (Eumetopias jubatus). Can J Zool 85:1-15

Tollit DJ, Schulze AD, Trites AW, Olesiuk P, Crockford SJ, Gelatt T, Ream R, Miller KM (2009) Development and application of DNA techniques for validating and improving pinniped diet estimates. Ecol Appl 19:889-905

Tollit DJ, Wong MA, Trites AW (2008) Steller sea lion prey selection in Frederick Sound, SE Alaska. Final report to NPUMMRC - NOAA 10:\#59

Traynor JJ (1996) Target-strength measurements of walleye pollock (Theragra chalcogramma) and Pacific whiting (Merluccius productus). ICES J Mar Sci 53:253-258

Trites AW, Donnelly CP (2003) The decline of Steller sea lions Eumetopias jubatus in Alaska: a review of the nutritional stress hypothesis. Mammal Rev 33:3-28

Trites AW, Joy R (2005) Dietary analysis from fecal samples: How many scats are enough? J Mammal 86:704-712

Trites AW, Larkin PA (1996) Changes in the abundance of Steller sea lions (Eumetopias jubatus) in Alaska from 1956 to 1992: How many were there? Aquat Mamm 22:153-166

Trites AW, Porter BT (2002) Attendance patterns of Steller sea 
lions (Eumetopias jubatus) and their young during winter. J Zool (Lond) 256:547-556

Trites AW, Porter BP, Deecke VB, Coombs AP, Marcotte ML, Rosen DAS (2006) Insights into the timing of weaning and the attendance patterns of lactating Steller sea lions (Eumetopias jubatus) in Alaska during winter, spring, and summer. Aquat Mamm 32:85-97

Trites AW, Calkins DG, Winship AJ (2007) Diets of Steller sea lions (Eumetopias jubatus) in Southeast Alaska, 19931999. Fish Bull (Wash DC) 105:234-248

Vollenweider JJ, Womble JN, Heintz RA (2006) Estimation of seasonal energy content of Steller sea lion (Eumetopias jubatus) diet. In: Trites AW, Atkinson SK, P. DD, Fritz LW, Gelatt TS, Rea LD, Wynne KM (eds) Sea lions of the world. Alaska Sea Grant College Program, AK-SG-06-01, University of Alaska, Fairbanks, AK, p 155-176

Wanless S, Harris MP, Redman P, Speakman JR (2005) Low energy values of fish as a probable cause of a major seabird breeding failure in the North Sea. Mar Ecol Prog Ser 294:1-8

Weise MJ, Harvey JT (2008) Temporal variability in ocean climate and California sea lion diet and biomass consumption: implications for fisheries management. Mar Ecol Prog Ser 373:157-172

> Williams TM, Rutishauser M, Long B, Fink T, Gafney J, Mostman-Liwanag H, Casper D (2007) Seasonal variability in

Editorial responsibility: Otto Kinne,

Oldendorf/Luhe, Germany otariid energetics: implications for the effects of predators on localized prey resources. Physiol Biochem Zool 80: 433-443

- Willson MF, Halupka KC (1995) Anadromous fish as keystone species in vertebrate communities. Conserv Biol 9: 489-497

- Winship AJ, Trites AW, Rosen DAS (2002) A bioenergetic model for estimating the food requirements of Steller sea lions Eumetopias jubatus in Alaska, USA. Mar Ecol Prog Ser 229:291-312

> Womble JN, Sigler MF (2006) Seasonal availability of abundant, energy-rich prey influences the abundance and diet of a marine predator, the Steller sea lion Eumetopias jubatus. Mar Ecol Prog Ser 325:281-293

Womble JN, Willson MF, Sigler MF, Kelly BP, VanBlaricom GR (2005) Distribution of Steller sea lions Eumetopias jubatus in relation to spring-spawning fish in SE Alaska. Mar Ecol Prog Ser 294:271-282

Womble JN, Sigler MF, Willson MF (2009) Linking seasonal distribution patterns with prey availability in a centralplace forager, the Steller sea lion. J Biogeogr 36:439-451

- York AE (1994) The population dynamics of northern sea lions, 1975-1985. Mar Mamm Sci 10:38-51

Zhao XY, Ona E (2003) Estimation and compensation models for the shadowing effect in dense fish aggregations. ICES J Mar Sci 60:155-163

Submitted: December 8, 2008; Accepted: June 3, 2009

Proofs received from author(s): August 5, 2009 